\title{
Donor's Motivation towards Providing Aid for Sustainable Initiatives: An Analysis of the Global Scenario
}

\author{
Zareena Begum Irfan ( $\boldsymbol{\sim}$ zareena@mse.ac.in ) \\ Madras School of Economics https://orcid.org/0000-0001-7253-9169 \\ Srihitha Baswapoor \\ Madras School of Economics
}

\section{Research}

Keywords: Sustainable production \& Consumption, Aid allocation, Rational Choice, Donor, Receptor

Posted Date: July 17th, 2020

DOI: https://doi.org/10.21203/rs.3.rs-38647/v1

License: (c) (1) This work is licensed under a Creative Commons Attribution 4.0 International License.

Read Full License 


\section{Abstract}

A substantial number of studies on development aid have explored the reasons for donor's aid allocation decisions, but very few exist for the Sustainable Production and Consumption (SP\&C) sector. This fails to provide evidence to policymakers to evaluate regarding inquiries about their allocative efficiency, equal allocation \& rhetoric with regard to international commitment of Sustainable Production and Consumption. This study examines donors' motivations to provide aid for the sustainable initiatives in general and sustainable production and consumption sector in particular using 35 donor and receptor countries worldwide between the time period 1992 and 2016. By examining four rational choice models, the results reveal that donors take into consideration their own self-interests as well as they cater to the recipients' needs for allocation of aid. The study also finds that, more aid is given to countries with good governance capabilities and thus do not prioritize fragile states.

\section{Introduction}

The importance of sustainable production and consumption has been long recognized in the global discourse, yet the Millennium Development Goals did not achieve the objective of achieving these patterns. Substantial number of studies on development aid have explored the reasons for donor's aid allocation decisions, but very few exist for the Sustainable Production and Consumption(SP\&C) sector. This fails to provide evidence to policymakers to evaluate regarding inquiries about their allocative efficiency, equal allocation \& rhetoric with regard to international commitment of Sustainable Production and Consumption. In lieu of this scenario, the study focuses to try and examine the donor's motivation for providing aid to SP\&C sector using 35 donor and receptor countries worldwide over different time periods between 1992-2016.

Sustainable Production and Consumption is one among the 17 SDG goals and ensures promoting resource and energy efficiency within the carrying capacity of the ecosystems and thus ensures better quality of life for all. It also aims to achieve sustainable infrastructure, access to basic services, green and decent jobs for all. This goal has direct linkages with goals' 6(Clean Water and Sanitation), 7(Affordable and Clean Energy), 8(Decent work and Economic Growth), and 13(Climate Action). Implementation of this goal helps us in achieving our overall development plans, reduce future economic, environmental and social costs, strengthen economic competitiveness and reduce costs. To achieve these goals, the DAC(Development Assistance Committee) along with other multilateral institutions provide aid to the DAC list of ODA(Official Development Assistance) recipients every year. The primary objective of the ODA is to promote economic development and welfare. A part of this ODA is diverted to green initiatives around the world. This can be seen from the evidence that total bi-lateral mitigationrelated aid commitments by members of the OECD's Development Assistance Committee (DAC) accounted around USD 16.1 billion per year in 2010-2011, rising over three fold since 2006, and thus representing $12 \%$ of the total official development assistance (OECD-DAC, 2013). In the year 2008-09, the DAC members on an average provided USD 9.3 billion in bilateral ODA to help developing countries reduce their own emissions, enhance greenhouse gas sinks or integrate climate change concerns in their 
development objectives. This represented total 7.1\% of their total bilateral ODA commitments in 2008-09 (OECD-DAC, 2011). Hence, in this study, ODA is considered as an important aid variable which provides assistance to the sustainable production and consumption sector too.

\section{Review Of Literature}

Whether aid serves the development needs of a recipient country rather the interests of the donors has been a topic of debate and research in the field of development studies. Donor agencies have interests, as does any other bureaucratic agency has dual interests consisting of both a formal and an informal mandate. Rahman and Giessen (2017) conceptualized the formal and informal interests of the donor bureaucracies in allocating aid using Bangladesh forest development aid by USAID, GIZ and EU as a case study. Important informal interests were classified into the categories political, economic and strategic which include increasing geo-political and policy influence in the recipient countries, expanding favorable markets for the donors' economy \& shaping good governance as a pre-requisite for investment in the receptor countries. Where as, the formal interests focused on delivering a formal development policy for the nation. The study reveals that US-AID supports their donors-self interests rather than the development objective unlike the other two.

Sumida(2017), explores the motivation of donor countries to provide educational aid based on four rational choice models. The study concludes that statistical evidence was found in two of the models; i.e, recipients needs model and good governance of the receptor countries. This reveals the fact that, the educational aid caters to the needs of the countries and the effectiveness of their governments in utilizing the aid.

Alessandro(2013), argued that aid can bolster growth and poverty reduction only in a conducive policy environment. The paper highlighted the fact that both; donors' poverty focused aid allocation and recipients' proper aid utilization are necessary to improve the aid effectiveness. This evidence was earlier supported by Kosack(2003), where he reveals that aid does not have effect on the quality of life in aggregate, it is effective when combined with democracy \& is inefficient in autocracies. Hence, the author suggests that more efforts need to go into democratization.

Irfan and Nehra (2016), analyzed the aid effectiveness on the health status and living standard in the urban sector using infant mortality rate and improved sanitation facilities as respective indicators. However, the result revealed that aid had not been effective in both the health and urbanization sector.

Chambers et al. (2018), studied two mechanisms based on improving environmental quality through aid. In the first mechanism, aid was allocated based on the improvement of environmental quality by each group with the potential of multiple groups receiving aid. In the second mechanism, aid is competitively allocated only to a single group that has initiated the greatest improvement of environmental quality. Surprisingly, the authors find that, the average level of environmental progress is lower in a competitive setting than in the setting with the potential for multiple recipients. 
Liu et al. (2017), studied the motives of consumers for eco-labelled rice in four provincial areas of China. The results reveal positive correlations between premiums for eco-labelled rice and consumers' concerns about food safety and the environment, suggesting that the health benefits and environmental considerations are the two critical motivations for the consumers to choose eco-labelled products.

Recent literature also reveals that ODA assistance is being diverted for sustainable initiatives like renewable power plants \& sustainable fisheries. Kim et al(2018), studied the South Korean people's willingness to pay for official development assistance to build renewable power plants in developing countries both to improve their electricity-related welfare and to reduce $\mathrm{CO}_{2}$ emissions globally. After surveying about 1000 households using the contingent valuation technique, to assess the Korean people's WTP for carrying out the ODA plan, it was found that the mean yearly WTP was USD 3.03 per household. For the next ten years $(2017$ - 2016), when the sample was expanded to the whole country, the WTP came out to be USD 58.5 million/annum. While the yearly cost of construction is estimated to be USD 35 million, clearly South Korean people's WTP is more than it.

In recent years, ODA funding has decreased for sustainable fisheries projects worldwide. Manus et al (2019), in their paper reveal that the UK government has committed to ring-fencing $0.7 \%$ GDP to international development assistance to support a wide range of programmes including sustainable fisheries and aquaculture. The authors re-iterated the fact that this could reduce poverty, increase the resilience of the fisheries sector to climate change; thereby increasing their food security. Primarily, this paper looks into the UK government support to the common wealth island states and UK overseas territories(OT). The paper thus sets out the emerging trends for ODA support and selects the important fisheries states eligible for the ODA commitment. Finally, this paper concluded by saying that such activities to sustainably develop the fisheries sector in Commonwealth states and UK OT, significantly enhance biodiversity protection and create opportunities to support "Blue-growth".

\section{Objective Of The Study}

From the extensive review of literature it could be observed that, donors have both formal and informal interests while funding the developing countries. Literature also reveals that historically, sectors like education, health and mortality have been prioritised over other sectors for aid allocation by the donors. Further studies conclude that countries are more concerned about their overall environmental quality and then finally about their eco-labelled products. The in between production and consumption part has been given least importance by both the developed and the developing world.

Thus, this paper tries to bridge this gap in literature by focusing on the motivation of the donors to provide aid for sustainable production and consumption.

\section{Theoretical Framework}


Following the previous literature, four rational choice models have been employed as a central framework to seek an explanation for donors' motivation in sustainable aid allocation. Rational choice theory is a theory for understanding and often formally modelling social and economic behaviour by focusing on individual agents who make choice. This theory is based on the premise that individual agents have preferences or rationales among the available choice alternatives and make their choices to maximize their happiness or utility (Edgeworth, 1881), which is therefore called rational choice. In the context of sustainable aid, it is assumed that a donor country has a certain rationale concerning which countries it likes to provide aid to, and it chooses countries to maximize its rationale. This rationale is particularly severe in the context of development aid, because this aid comprises not eternal but very limited resources, and donor countries attempt to exploit the most resources to pursue their rationale. Some rationales depend on the context, for instance, happiness, utility, and efficiency. Following the general aid discussions, four models of rationales are examined in this study. These four models are donors' self interests, recipients' needs, good governance models of both the donor and the receptor \& fragile state priority. Figure 1 shows a diagram of the rational choice model of sustainable aid which has been created for this study.

\section{Data And Methodology}

The data used in this study are panel data that is gathered from several sources including international organizations, governmental institutes, NGO's and these data are publically available through the sources website. Due to the paucity of data, the analysis has been done for 35 countries worldwide over different time periods. The detailed list of countries is given in the appendix(will write towards the end). Table 5.1 lists the four different models along with the time period of their study and respective observations. Each of the four models mentioned above have been examined separately to understand the priorities of the donor countries while allocating aid for sustainable initiatives. This has been explained elaborately in Sect. $6,7,8 \& 9$.

Table 5.1

Rational Choice Models with time period of study and observations

\begin{tabular}{|lllll|}
\hline $\begin{array}{l}\text { Four Rational } \\
\text { Choice Models }\end{array}$ & $\begin{array}{l}\text { Time period of } \\
\text { Analysis }\end{array}$ & $\begin{array}{l}\text { Number of } \\
\text { observations(N) }\end{array}$ & $\begin{array}{l}\text { Number of } \\
\text { years(n) }\end{array}$ & $\begin{array}{l}\text { Number of } \\
\text { countries(T) }\end{array}$ \\
\hline $\begin{array}{l}\text { I. Donors' Self } \\
\text { Interests }\end{array}$ & $2006-2016$ & 132 & 11 & 12 \\
\hline $\begin{array}{l}\text { II. Recipients' Needs } \\
\text { III. Good }\end{array}$ & $1992-2016$ & 575 & 25 & 23 \\
$\begin{array}{l}\text { Governance(R) } \\
\begin{array}{l}\text { IV. Fragile State } \\
\text { Priority }\end{array}\end{array}$ & $1992-2016$ & 575 & 25 & 23 \\
\hline
\end{tabular}

However, the good governance model has been run for both the donor and the receptor countries to try and understand if the governance in both these countries is affecting the aid given/received by them. The 
good governance model in the table in row III is for the receptor countries. The time period of analyses and the number of observations for the good governance of the donor countries is similar to that of row l; that is of donor's self interest model. The following sections discuss the results of each of these four models in detail.

\section{Results And Discussions}

\subsection{Model I - Donors' Self Interests}

The first model is the donors' self interests' that signifies what donors' expect to receive in return for providing development aid. Todaro and Smith(2009) in their study indicated that donors' primary motivation to provide aid is either a political strategy or economic self-interest. They also stressed on the fact that donor government's diplomatic strategy influences the aid allocation to the recipient country. This motivation seems inevitable because the policy decisions of donor governments are influenced by many factors that form the domestic conditions, such as value, political party affiliation, constituency interest, public opinion, the country's deference and decision rules and global competition or alliances (Anderson, 1997). Therefore, a donor country's aid allocation decisions must become self strategic sometimes to satisfy the best conditions for the donor.

Several studies have shown a strong association between bilateral aid and a donor's political and economic interests, while the indicators used in the analysis varies as the context changes. An early study by Wittkopf (1972) examines the aid motivation for major donors and finds that the variable of Cold War considerations was the most important factor in the 1960s for aid allocation from the United States. In a series of other case studies of major donors, namely, United Kingdom, Germany, France and the United States - gross term of international liquidity holding, military expenditures, association with communist parties, gross expenditure on the armed forces, GDP and Population were identified as important political indicators. The authors of these series conclude that political interests provide a decent explanation for the aid allocation by these 4 countries in 1960's. After the end of the cold war in 1989, few of the scholars constructed a new variable for political interests of the donors' like Voting pattern in the UN by calculating the correlation of the donor and recipient country's voting record in the UN General Assembly and find that the UN voting pattern is a highly important driver of aid allocation, particularly for Japan's development aid between 1970 and 1994 (Alesina and Dollar, 2000). Kuziemko and Weker (2006), have revealed that the volume of the development aid from the UN and the United States increases if they notice that the developing country serves a seat on the UN security council. A more recent study by Fuchs and Vadlamannati (2013) on the aid from India from 2008 to 2010 also confirms that the voting pattern in the $\mathrm{UN}$ is a significantly important factor that relates to aid allocation.

In various other studies, several economic interests variables have been found out to have strong associations with regard to the overall aid allocation. Davenport(1970) in his study finds out that among several other variables foreign reserve position has been consistently significant. Variable of Trade balance used by Wittkopf (1972) in his study was also a strong explanatory factor for British, German 
and French aid. McKinlay and Little (1977, 1978 a,b, 1979) and McKinlay (1978) have confirmed the importance of gross size of exports and imports, net balance of private investment as important indicators of donors' aid allocation. Younas (2008) also confirms the strong association between aid and trade-related indicators but more specifically shows that donors favour countries that import the goods in which the donor country has a comparative advantage in production.

Thus, after a careful analysis of previous literature on aid allocation, the following variables have been used for the present study.

\subsection{Variables used in the Regression Analysis}

Following the previous literature, the variables described below have been used for the current study.

\section{Dependent variable}

Net ODA Given (log)

Since this model is the donor's self interests' model, Official Development Assistance given is considered as $Y$ variable. The rationale for using this variable is to understand how the donor country's aid given is being affected by their own vested self interests.

\section{Independent variables}

UN Security Council seat, Gross size of exports, Government expenditure, Total reserves and Net International Investment Position

In this study, we consider Coal production, Coal consumption and Co2 emissions variables as our indicators of sustainable production and consumption. We all know that $\mathrm{CO}_{2}$ emissions are the major pollutants of the environment and $87 \%$ percent of all human-produced carbon di-oxide emissions come from the burning of fossil fuels like coal, natural gas and oil. The primary reason behind selecting coal is because it is solely responsible for $43 \%$ of the $\mathrm{CO} 2$ emissions coming from the energy sector (Le Quere et al, 2013).

Thus, in this model, we take into account coal production, coal consumption and Co2 emissions of 12 donor nations to understand whether the donor country's own sustainable indicators influence their decisions of providing aid to the developing world. Table 6.2.1 lists the variables used in the donors self interests models' regression along with their definition and sources. 
Table 6.2.1

Donors' Self - Interests model variables and sources

\section{VARIABLES}

Aid Given

i) Net ODA given
DEFINITION development \& welfare (MN_USD\$)
Government aid given/received for economic

SOURCES

World bank \& OECD

United Nation

World Bank

Our World in

Data(IMF)

Total reserves(includes gold, mn_usd)

Investment Position(Creditor/Debtor)
World Bank

IMF

iv) Total Reserves

v) Net international investment position

\section{Sustainable indicators Coal Production by country(mn_ton)}

i) Coal Production

ii) Coal Consumption

iii) CO2 Emissions
Coal Consumption by country(mn_ton)

Annual CO2 emissions per country

GDP Per Capita, current US\$

Population, total( in thousands)
International Energy

Statistics

B.P Statistical Review of Global Energy

Global Carbon

Project,2017

World Bank

World Bank

i)GDP Per Capita

ii) Population

The Net ODA given data are drawn from the Organization of Economic Co-operation and Development (OECD) Development Assistance Committee (DAC)'s Creditor Reporting System (CRS) data base, which is self-reported information by the DAC countries. Official development assistance (ODA) is defined as government aid designed to promote economic development and welfare of developing countries. Loans and credits for military purposes are excluded. Aid may be provided bilaterally, from donor to recipient, or channelled through a multilateral development agency such as the United Nations or the World bank. The OECD maintains a list of developing countries and territories; only aid to these countries counts as ODA. A long-standing United Nations target is that developed countries should devote $0.7 \%$ of their gross national income to ODA. This indicator is measured as a percentage of gross national income and million USD constant prices, using 2015 as the base year.

The data period spans 10 years beginning in 2006 until the most recent collection of data in 2016. Over this period, the data set covers 11 aid-donor countries in total, excluding a few due to data constraints. 
The information regarding donors' political interests is measured by a dummy variable for having a seat on the UN Security Council. The primary aim of the UN Security Council is to maintain global peace and thus it is given the power to authorize multilateral sanctions and military action when an unsecured event occurs, such as during a war or invasion by countries. Holding a seat on the UN Security council means that the country has a representative role in making decisions on behalf of all UN member states for significant/major world events. Therefore, the study hypothesized that some donor countries, might want to increase the development aid if they possess a UN Security council seat to reflect their political will on the Council. Earlier studies by Kuziemko and Werker (2006) reveal that in case of aid from the US and the UN, political interests were significantly related to the volume of development aid and they increased US aid by $59 \%$ and UN aid by $8 \%$ respectively. Donors' economic interests have been captured by two variables specifically exports \& total reserves. These variables are indicators of the donors' trading capacity. Net international investment position has also been considered as an independent variable to observe whether how a country's position of being a debtor or a creditor is affecting the aid given by them.

Following the previous literature, the study also accounts for the effect of potential confounding variables. This process is necessary to observe the effect of the included variables by ensuring that their remaining effect is not due to omitted variable bias. As informed by the previous literature, natural logarithm of GDP per capita and total population were included. Both data are drawn from the World Development Indicators.

\subsection{Model Specification}

Since the data used in this study is panel data that has two dimensions, namely donor country

and time, firstly, the benchmark fixed effects model includes country-fixed effects to control for the unobserved country- specific and time invariant factor determinants of aid. Thus the specification shown in Eq. 1 includes two groups of explanatory variables and control variables.

\section{Donors Self Interests Fixed effects Model}

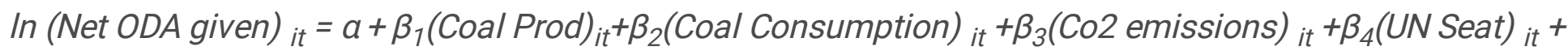
$\beta_{5}$ (Exports) $_{i t}+\beta_{6}$ (Total Reserves) $_{i t}+\beta_{7}\left(\right.$ Government Expenditure) ${ }_{i t}+\beta_{8}\left(\right.$ Net Investment position) ${ }_{i t}+\delta X_{i t}$ $+u_{i}+\varepsilon_{i t}-(1)$

where the dependent variable $\mathrm{Aid}_{\mathrm{it}}$ is the amount of ODA provided to the recipient country $i$ in period $t$. The three variables coal production, coal consumption and $\mathrm{CO}_{2}$ emissions represent our sustainable variables of donor country $i$ in period $t$. These three variables exhibited strong multi-collinearity and were thus included one by one in the estimation. Therefore these three variables were estimated separately in three different models. For the other variables, variance inflation factors (VIF's) were calculated to check whether multi-collinearity caused a problem in the estimation, but could not find any evidence that suggests that it seriously affected the estimation results. Variables like UN Seat, Exports, Total reserves, 
Government expenditure and Net international Investment position capture the donor's political \& commercial interests in country $i$ for period $t . \mathrm{X}_{\mathrm{it}}$ is the control variables of GDP Per capita and total population of country $i$ in period $t$. The term $\mathrm{u}_{\mathrm{i}}$ is the country fixed effects and denotes the time-invariant differences in providing aid across the donor countries and $\varepsilon_{i t}$ is the error term in the model.

After performing the Hausman test for fixed effects and random effects, the null hypothesis of random effects model is appropriate was rejected and hence fixed effects estimation has been used in this model and its results are as given below in Table 6.3.1 
Table 6.3.1

Relation between Net ODA given \& donors' self interests: FE regression

\begin{tabular}{|c|c|c|c|}
\hline & \multicolumn{3}{|c|}{ Fixed effects Estimation } \\
\hline & $\begin{array}{l}\text { Coal Produ } \\
\text { (1) (2) (3) }\end{array}$ & Coal Consu & $\mathrm{CO}_{2}$ emissions \\
\hline Donors' Self Interests & -0.064 & -0.066 & -0.07 \\
\hline UN Security Council seat & $(0.062)$ & $(0.061)$ & $(0.061)$ \\
\hline Exports & -0.013 & -0.013 & -0.015 \\
\hline Government expenditure & $(0.008)$ & $(0.008)$ & $(0.008)$ \\
\hline Total Reserves & $-0.014^{\star \star}$ & $-0.014^{\star *}$ & $-0.014^{\star \star}$ \\
\hline Net International Investment Position & $(0.006)$ & $(0.006)$ & $(0.006)$ \\
\hline Sustainable variables & $-2.63 e^{-07}$ & $-2.89 e^{-07}$ & $-4.03 e^{-07}$ \\
\hline Coal Production & $\left(3.10 e^{-07}\right)$ & $\left(3.12 \mathrm{e}^{-07}\right)$ & $\left(3.26 \mathrm{e}^{-07}\right)$ \\
\hline Coal Consumption & 0.085 & 0.081 & 0.071 \\
\hline $\mathrm{CO}_{2}$ Emissions & $(0.093)$ & $(0.093)$ & $(0.093)$ \\
\hline Control Variables & -0.0002 & -0.0007 & -0.0003 \\
\hline GDP Per Capita (log) & $(0.0004)$ & $(0.0009)$ & $(0.0002)$ \\
\hline Population (log) & 0.07 & 0.061 & 0.089 \\
\hline Constant & $(0.17)$ & $(0.17)$ & $(0.17)$ \\
\hline Observations & $2.19^{\star \star \star}$ & $2.02^{\star \star}$ & $1.846^{\star \star}$ \\
\hline R-squared & $(0.77)$ & $(0.80)$ & $(0.81)$ \\
\hline & $-29.57^{\star \star}$ & $-26.57^{*}$ & $-23.36^{*}$ \\
\hline & (13.07) & (13.6) & (13.7) \\
\hline & 132 & 132 & 132 \\
\hline & 0.70 & 0.69 & 0.65 \\
\hline
\end{tabular}

Note

Standard errors in parentheses, $* \star \star p<0.01, * \star p<0.05, * p<0.1$

Second, the study also included lagged dependent variable in the analysis performed because donors' tend to allocate aid to a country that has already received a certain amount of aid, rather to a country they 
do not know about; thus it is hypothesized that the aid flows in the current period tend to be related to the previous periods' aid allocation. This new specification including lagged version of the dependent variable as one of the independent variable is given in Eq. 2.

\section{Donors Self Interests Lagged Dependent variable Model}

In (Net ODA given) $)_{i t}=a+\rho$ Aid $_{t-1}+\beta_{1}$ (Coal Production) $)_{i t}+\beta_{2}$ (Coal Consumption $)_{i t}+\beta_{3}\left(\mathrm{CO}_{2}\right.$ emissions) ${ }_{i t}+\beta_{4}(\text { UN Seat })_{i t}+\beta_{5}$ (Exports) $_{i t}+\beta_{6}$ (Total Reserves) $_{\text {it }}+\beta_{7}$ (Govt Expenditure) $)_{i t}+\beta_{8}$ (Net Investment position) ${ }_{i t}+\delta X_{i t}+u_{i}+\varepsilon_{i t}-(2)$

The results of the model are presented in Table 6.3.2 
Table 6.3.2

Relation between Net ODA given \& donors' self interests: Lag dependent variable model, FE regression

Lagged Dependent Variable model : Fixed effects Estimation

Coal Production Coal Consumption $\mathrm{CO}_{2}$ emissions

(1) (2) (3)

\begin{tabular}{|c|c|c|c|}
\hline Donors' Self Interests & -0.036 & -0.038 & -0.043 \\
\hline UN Security Council seat & $(0.062)$ & $(0.061)$ & $(0.061)$ \\
\hline Exports & -0.008 & -0.008 & -0.01 \\
\hline Government expenditure & $(0.008)$ & $(0.008)$ & $(0.009)$ \\
\hline Total Reserves & $-0.011^{*}$ & $-0.011^{*}$ & $-0.012^{\star}$ \\
\hline Net International Investment Position & $(0.006)$ & $(0.006)$ & $(0.006)$ \\
\hline Sustainable variables & $-2.83 e^{-07}$ & $-3.01 e^{-07}$ & $-4.03 e^{-07}$ \\
\hline Coal Production & $\left(3.06 \mathrm{e}^{-07}\right)$ & $\left(3.08 e^{-07}\right)$ & $\left(3.21 \mathrm{e}^{-07}\right)$ \\
\hline Coal Consumption & 0.043 & 0.040 & 0.032 \\
\hline $\mathrm{CO}_{2}$ Emissions & $(0.093)$ & $(0.093)$ & $(0.093)$ \\
\hline Control Variables & -0.0002 & -0.0006 & -0.0003 \\
\hline GDP Per Capita (log) & $(0.0004)$ & $(0.0009)$ & $(0.0002)$ \\
\hline Population (log) & 0.08 & 0.077 & 0.097 \\
\hline Lagged dependent variable (t-1) & $(0.18)$ & $(0.181)$ & $(0.179)$ \\
\hline & $1.83^{\star *}$ & $1.71^{\star *}$ & $1.53^{*}$ \\
\hline Observations & $(0.78)$ & $(0.81)$ & $(0.82)$ \\
\hline R-squared & $0.107^{\star \star}$ & $0.106^{\star *}$ & $0.103^{\star \star}$ \\
\hline & $(0.78)$ & $(0.043)$ & $(0.043)$ \\
\hline & $-24.6^{*}$ & -22.3 & -19.15 \\
\hline & $(13.34)$ & $(13.9)$ & $(14.05)$ \\
\hline & 131 & 131 & 131 \\
\hline & 0.72 & 0.72 & 0.68 \\
\hline
\end{tabular}

Note

Standard errors in parentheses, ${ }^{* *} p<0.01, * * p<0.05,{ }^{*} p<0.1$ 
However, in this kind of model specification, Aid $_{\mathrm{it}-1}$ is correlated with the fixed effects in the error term $\varepsilon_{i t}$ which gives rise to a 'dynamic panel bias' (Nickell, 1981). This phenomenon could inflate the co-efficient estimate for the lagged aid variable by attributing predictive power to it that actually belongs to the country's fixed effects. Thus, it could reduce the impact of one-year's shock on a country's apparent fixed effects and thereby diminishing endogeneity problem too. To solve these problems, the system generalized method of moments (GMM) estimation developed by Arellano and Bond (1991) has been used. GMM solves the endogenous bias problem that relates to the inclusion of the lagged dependent variables and instrumental variables for other possible endogenous variables. It also addresses the independent variables that are not exogenous, as well as the fixed effects, heteroskedasticity and autocorrelation within countries. The estimation has been run by building a set of two equations, including the original equation in Eq. 2 and the transformed equation or the differenced equation, as specified in Eq. 3.

\section{Donors Self Interests GMM Model}

In $(\Delta \text { Net ODA given })_{i t}=\rho\left(\Delta\right.$ Aid $\left._{i t-1}\right)+\beta_{1}(\Delta \text { Coal Prod })_{i t}+\beta_{2}(\Delta \text { Coal Consumption })_{i t}+\beta_{3}(\Delta$ CO2 emissions) $)_{i t}+\beta_{4}(\Delta U N \text { Seat })_{i t}+\beta_{5}\left(\Delta\right.$ Exports $_{i t}+\beta_{6}(\Delta \text { Total Reserves })_{i t}+\beta_{7}(\Delta \text { Government Expenditure })_{i t}+\beta_{8}(\Delta$ Net Investment position $)_{i t}+\delta\left(\Delta X_{i t}\right)+\Delta \varepsilon_{i t}-(3)$

The lagged difference in the endogenous variables is used as an instrument for the original equation, and the lagged levels of the endogenous variables are used as an instrument for the transformed equation. The results of the system GMM specification are presented below in Table 6.3.3. 
Table 6.3.3

Relation between Net ODA given \& donors' self interests: GMM model

\begin{tabular}{|c|c|c|c|}
\hline & \multicolumn{3}{|c|}{ GMM Estimation } \\
\hline & \multicolumn{3}{|c|}{ Coal Production Coal Consumption $\mathrm{CO}_{2}$ emissions } \\
\hline & \multicolumn{3}{|l|}{ (1) (2) (3) } \\
\hline Donors' Self Interests & 0.020 & 0.013 & 0.009 \\
\hline UN Security Council seat & $(0.053)$ & $(0.053)$ & $(0.054)$ \\
\hline Exports & -0.004 & -0.004 & -0.004 \\
\hline Government expenditure & $(0.008)$ & $(0.008)$ & $(0.008)$ \\
\hline Total Reserves & $-0.014^{\star *}$ & $-0.014^{\star \star \star}$ & $-0.015^{\star \star \star}$ \\
\hline Net International Investment Position & $(0.005)$ & $(0.005)$ & $(0.005)$ \\
\hline Sustainable variables & $6.29 \mathrm{e}^{-08}$ & $2.21 \mathrm{e}^{-08}$ & $-1.84 \mathrm{e}^{-08}$ \\
\hline Coal Production & $\left(2.91 e^{-07}\right)$ & $\left(2.98 \mathrm{e}^{-07}\right)$ & $\left(3.07 \mathrm{e}^{-07}\right)$ \\
\hline coal consumption & 0.095 & 0.094 & 0.092 \\
\hline $\mathrm{CO}_{2}$ Emissions & $(0.131)$ & $(0.13)$ & $(0.131)$ \\
\hline Control Variables & -0.0003 & -0.0011 & -0.0002 \\
\hline GDP Per Capita (log) & $(0.0006)$ & $(0.0014)$ & $(0.0002)$ \\
\hline Population (log) & -0.264 & -0.26 & -0.25 \\
\hline Constant & $(0.17)$ & $(0.17)$ & $(0.172)$ \\
\hline Observations & $2.41^{\star \star \star}$ & $2.19^{\star \star}$ & $2.22^{\star \star}$ \\
\hline R-squared & $(0.81)$ & $(0.91)$ & $(0.86)$ \\
\hline & $-30.02^{\star \star}$ & -26.2 & -26.5 \\
\hline & (13.96) & (15.6) & (14.79) \\
\hline & 108 & 108 & 108 \\
\hline & 0.75 & 0.72 & 0.70 \\
\hline
\end{tabular}

Note

Standard errors in parentheses, $* \star \star p<0.01, * \star p<0.05, * p<0.1$

Tables 6.3.1, 6.3.2 \& 6.3.3 show the results of association of donors self interests variables with log Net ODA given. In the FE regression, all of the specifications show a moderate fitness to the regression lines, 
with R-squared values between 0.6 and 0.7. Similarly, the lagged dependent variable model also has a moderate fit, with R-squared values from 0.68 to 0.72 . In all the three estimations above (FE, lagged dependent variable model \& GMM), government expenditure and population have been significant throughout across models (1), (2) \& (3), i.e, coal production, coal consumption \& $\mathrm{CO}_{2}$ emissions. Government expenditure is a donors' self interest variable whereas population is a control variable. This evidence reveals that the donor country's increase aid allocation for sustainable initiatives to a receptor country as their own government expenditure is lowered. Results also state that as a donor country's population is increasing, their aid allocation to receptor countries is growing. This can be seen from the positive co-efficient of the population (log) variable. The variable of a seat on the UN Security Council showed no significant relation in all specifications. Variables like total reserves \& net investment position also did not reveal significant results. From these results, it is clear that donors' do not provide more aid to countries based on their political interests but they do provide more aid to countries based on their economic interests as revealed by the government expenditure variable.

The sustainability indicators considered in the model also did not reveal significance across the models and thus makes the point clear that donors are not concerned much about their own production, consumption \& emissions while giving aid to recipient countries for sustainable initiatives. Overall, donor country's increase their sustainable aid allocation as their own government expenditure falls and their population is rising.

\section{Model li}

\subsection{Recipient's Needs Model}

The second model is based on equity allocations, which is a more specific term for the need principle and thus states that donors provide more aid to countries that are most in need. The definition of equity differs depending on the context. In some cases, equity might mean that allocation of resources are based on the efforts that one exerts or in some other cases it may mean that same amount of resources are allocated without considering any conditions. In the context of international sustainable aid, equity is generally considered in terms of the need principle. This model is related to a humanitarian motive, where donors are expected to be ethical in their decisions and provide aid to countries with the most expansive needs for sustainable development. This model, thus analyses development aid overall.

However, the model has only explained aid when this aid is conditioned by a certain category, such as aid sector, donor type etc. Maizels and Missanke (1984),conditioned their aid model by donor type \& showed that their model explained multilateral aid allocation in the 1970's by measuring needs with three proxies of GDP per- capita, Physical quality of life index (PQLI) and the balance-of-payments current account to GDP. Claessens et al. (2009) proved that between 1990 to 2004, bilateral aid also responded to poverty needs as measured by GDP per capita and population. A study by Dreher et al. (2011) revealed that old/traditional donors are more responsive to the recipients needs than the emerging/new donors, and they measured this by GDP per capita, mortality rate, malnutrition, people who are affected by a disaster 
and the human development index. By focusing on multilateral aid donors from 1983 to 1997, Neumayer (2003) showed that the regional bank generally focuses on economic needs as measured by per capita income, whereas the UN agencies consider human development needs in their allocation such as the PQLI. Few other studies by Maizels and Missanke (1984) which were performed by comparing the aid allocation by period, revealed that the aid before 1970's was based more on the needs than the aid between 1970's and 1980's.

Scholars have also examined the relation between development aid and specific sector needs and have found some connections between them. Neumayer (2005), shows that the flow of development aid follows the level of food needs, as measured by the average calorie supply per-capita and domestic food self-sufficiency index in the case of four large donors from the EU, US, UN World food programme and the NGO's in the 1990's. Nelson(2010), investigates the responsiveness of overall development aid to different sector-level needs between 1981 and 2004 and finds that overall development aid has been responsive to three sectors; i.e, food sector, energy and the education sector. Fielding(2011), finds that in the health sector, volume of health aid is also responsive to the health needs. Similarly, Lee and Lim(2014), examine three major health indicators, namely the IMR, child mortality rate and HIV prevalence rate, and show that donors respond to these indicators as shown by the increase in the total volume of health aid as the deterioration level of health status increases. Though there is sufficient literature on sector wise needs like health, education etc., hardly any literature exists on the needs of production \& consumption sector. Thus, drawing from the previous literature on aid allocation, this model tries to use the following variables for the sustainable production \& consumption sector needs along with other general ones.

\subsection{Variables used in the Regression Analysis}

Along with the variables used in previous literature, few new variables have also been used in this model. They are as follows:

\section{Dependent Variable}

Net ODA Received (log)

Since this model is the recipient's needs model, Official Development Assistance received is considered as the $\mathrm{Y}$ variable. The rationale for using this variable is to understand to what extent, the aid received by the receptor countries is being affected by their level of needs.

\section{Independent Variables}

Following the previous literature, Human Development Index \& Mortality rate were chosen as general needs variables.

Other than them; as mentioned earlier, in this model, we consider Coal production, Coal consumption and Co2 emissions variables of the recipient countries as our indicators of sustainable production and 
consumption. The primary reason behind selecting coal is because it is responsible for $43 \%$ of the $\mathrm{CO} 2$ emissions coming from the energy sector (Le Quere et al, 2013).

Thus, in this model, we take into account coal production, coal consumption and Co2 emissions of 23 receptor nations to try and understand whether the donor country's aid allocation decisions are being influenced by the performance of these needs variables in the receptor countries. Table 7.2.1 lists the variables used in the recipient needs model regression along with their definition and sources.

Table 7.2.1

Recipients needs model variables and sources

\begin{tabular}{|c|c|c|}
\hline VARIABLES & DEFINITION & SOURCES \\
\hline $\begin{array}{l}\text { Aid Received } \\
\text { i)Net ODA } \\
\text { Received }\end{array}$ & $\begin{array}{l}\text { Government aid received for economic } \\
\text { development \& welfare (MN_USD\$) }\end{array}$ & World bank \\
\hline $\begin{array}{l}\text { Recipient } \\
\text { Country Needs }\end{array}$ & Coal Production by country(mn_ton) & $\begin{array}{l}\text { International Energy } \\
\text { Statistics }\end{array}$ \\
\hline $\begin{array}{l}\text { i) Coal } \\
\text { Production }\end{array}$ & Annual $\mathrm{CO}_{2}$ emissions per country & $\begin{array}{l}\text { B.P Statistical Review of } \\
\text { Global Energy }\end{array}$ \\
\hline $\begin{array}{l}\text { ii) Coal } \\
\text { Consumption }\end{array}$ & \multirow{4}{*}{$\begin{array}{l}\text { Higher Index( better development) } \\
\text { Mortality rate( per } 1000 \text { births) }\end{array}$} & \multirow{2}{*}{$\begin{array}{l}\text { Global Carbon } \\
\text { Project,2017 } \\
\text { UNDP Human } \\
\text { development reports }\end{array}$} \\
\hline $\begin{array}{l}\text { iii) } \mathrm{CO}_{2} \\
\text { Emissions }\end{array}$ & & \\
\hline iv) HDI & & \multirow[t]{2}{*}{ World Bank } \\
\hline v) Mortality rate & & \\
\hline Control & GDP Per Capita, current US\$ & World Bank \\
\hline $\begin{array}{l}\text { i) GDP Per } \\
\text { Capita }\end{array}$ & \multirow[t]{2}{*}{ Population, total( in thousands) } & \multirow[t]{2}{*}{ World Bank } \\
\hline ii) Population & & \\
\hline
\end{tabular}

The Net ODA received data are drawn from the World Bank development indicators database. Official development assistance (ODA) is defined as government aid designed to promote economic development and welfare of developing countries. Loans and credits for military purposes are excluded. Aid may be provided bilaterally, from donor to recipient, or channelled through a multilateral development agency such as the United Nations or the World bank. Net Official Development Assistance (ODA) consists of disbursements of loans made on concessional terms ( net of repayments of principal) and grants by official agencies of the members of the Development Assistance Committee (DAC), by multilateral institutions, and by non-DAC countries to promote economic development and welfare in countries and 
territories in the DAC list of ODA recipients. It includes loans with a grant element of at least $25 \%$ (calculated at a rate of discount of $10 \%$ ). Data are in million US dollars.

The data period spans for 25 years beginning in 1992 until the most recent collection of data in 2016 . Over this period, the data set covers 23 aid-recipient countries in total, excluding a few due to data constraints.

The needs of a recipient country are captured by the following five indicators that represent the sustainability level of a recipient country in different aspects: Coal Production, Coal Consumption, $\mathrm{CO}_{2}$ emissions, HDI \& mortality rate. The reason for selecting these indicators was that the international community recognizes both the components of HDI and mortality as fundamental needs in the developing countries, and these indicators have also been used to measure the global targets in both the Millennium Development Goals and Sustainable Development Goals. Sustainable Production \& Consumption is an important ecological goal of the SDG's and hence coal production, consumption \& $\mathrm{CO}_{2}$ Emissions were selected to assess the needs of the developing countries for this goal.

Following the previous literature, the model also accounts for the effect of potential confounding variables. This process is necessary to observe the effect of the included variables by ensuring that their remaining effect is not due to omitted variable bias. As informed by the previous literature, natural logarithm of GDP per capita and total population were included. Both data are drawn from the World Development Indicators.

\subsection{Model Specification}

Since the data used in this study is panel data that has two dimensions, namely receptor country and time, firstly, the benchmark fixed effects model includes country-fixed effects to control for the unobserved country- specific and time invariant factor determinants of aid. Thus the specification shown in Eq. 4 includes one group of explanatory variables (i.e, needs variables) and control variables.

\section{Recipient needs Fixed effects Model}

In (Net ODA received) ${ }_{i t}=a+\beta_{7}(\text { Coal Prod })_{i t}+\beta_{2}(\text { Coal Consumption) })_{i t}+\beta_{3}\left(\mathrm{CO}_{2}\right.$ emissions) ${ }_{i t}+\beta_{4}(\mathrm{HDI})_{i t}+$ $\beta_{5}(\text { Mortality rate) })_{\text {it it }}+\delta X_{i t}+u_{i}+\varepsilon_{i t}-(4)$

where the dependent variable $\mathrm{Aid}_{\mathrm{it}}$ is the amount of ODA received by the recipient country $i$ in period $t$. The three variables coal production, coal consumption and $\mathrm{CO}_{2}$ emissions represent our sustainable variables of recipient country $i$ in period $t$. Similar to the previous model, these three variables exhibited strong multi-collinearity and were thus included one by one in the estimation. Therefore these three variables were estimated separately in three different models. For the other variables, variance inflation factors (VIF's) were calculated to check whether multi-collinearity caused a problem in the estimation, but could not find any evidence that suggests that it seriously affected the estimation results. Variables like $\mathrm{HDI} \&$ Mortality rate capture the recipient's fundamental needs in country $i$ for period $t . \mathrm{X}_{i \mathrm{t}}$ is the control 
variables of GDP Per capita and total population of country $i$ in period $t$. The term $\mathrm{u}_{\mathrm{i}}$ is the country fixed effects and denotes the time-invariant differences in receiving aid across the recipient countries and $\varepsilon_{i t}$ is the error term in the model.

After performing the Hausman test for fixed effects and random effects, the null hypothesis of random effects model is appropriate was rejected and hence fixed effects estimation has been used in this model and its results are as given below in Table 7.3.1

Table 7.3.1

Relation between Net ODA received \& Recipients needs: FE regression

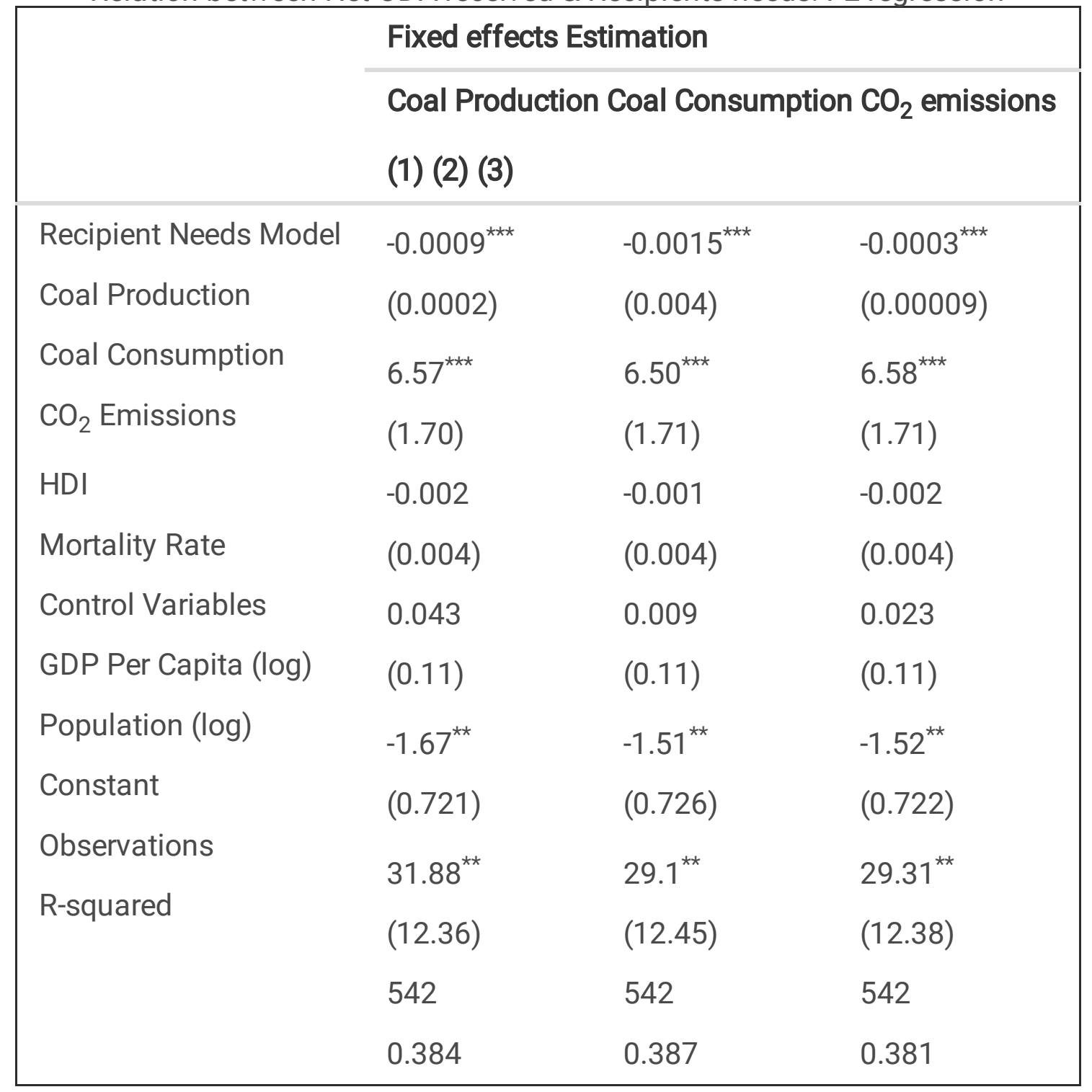

\section{Note}

Standard errors in parentheses, $* \star \star p<0.01, * \star p<0.05, * p<0.1$

Second, the study also included lagged dependent variable in the analysis performed because donors' tend to allocate aid to a recipient country that has already received a certain amount of aid, rather to a country they do not know about; thus it is hypothesized that the aid flows in the current period tend to be 
related to the previous periods' aid allocation. This new specification including lagged version of the dependent variable as one of the independent variable is given in Eq. 5.

\section{Recipient needs Lagged dependent variable model}

In (Net ODA received) $)_{i t}=a+\rho$ Aid $_{t-1}+\beta_{1}(\text { Coal Prod })_{i t}+\beta_{2}$ (Coal Consumption) $)_{i t}+\beta_{3}\left(\mathrm{CO}_{2}\right.$ emissions) it $+\beta_{4}(H D I)_{i t}+\beta_{5}$ (Mortality rate) $_{i t ~ i t}+\delta X_{i t}+u_{i}+\varepsilon_{i t}-(5)$

The results of the model are presented in Table 7.3.2

Table 7.3.2

Relation between Net ODA received \& Recipients needs: Lagged dependent variable regression

\begin{tabular}{|c|c|c|c|}
\hline & \multicolumn{3}{|c|}{$\begin{array}{l}\text { Lagged Dependent Variable Model : } \\
\text { Fixed effects Estimation }\end{array}$} \\
\hline & $\begin{array}{l}\text { Coal Prodt } \\
\text { (1) (2) (3) }\end{array}$ & Coal Consu & $\mathrm{CO}_{2}$ emissions \\
\hline Recipient Needs Model & $-0.0006^{\star \star \star}$ & $-0.001^{\star \star \star}$ & $-0.0002^{\star \star \star}$ \\
\hline Coal Production & $(0.0001)$ & $(0.0003)$ & $(0.00008)$ \\
\hline Coal Consumption & $4.82^{\star \star \star}$ & $4.71^{\star \star \star}$ & $4.76^{\star \star \star}$ \\
\hline $\mathrm{CO}_{2}$ Emissions & $(1.44)$ & $(1.45)$ & $(1.45)$ \\
\hline $\mathrm{HDI}$ & 0.004 & 0.004 & 0.004 \\
\hline Mortality Rate & $(0.004)$ & $(0.004)$ & $(0.004)$ \\
\hline Control Variables & -0.017 & -0.044 & -0.035 \\
\hline GDP Per Capita (log) & $(0.09)$ & $(0.09)$ & $(0.093)$ \\
\hline Population (log) & -0.44 & -0.29 & -0.30 \\
\hline Lagged dependent variable $(\mathrm{t}-1)$ & $(0.631)$ & $(0.634)$ & $(0.630)$ \\
\hline Constant & $0.413^{\star \star \star}$ & $0.419^{\star \star \star}$ & $0.418^{\star \star \star}$ \\
\hline Observations & $(0.034)$ & $(0.034)$ & $(0.034)$ \\
\hline R-squared & 8.50 & 5.88 & 6.08 \\
\hline & $(10.87)$ & $(10.9)$ & $(10.87)$ \\
\hline & 526 & 526 & 526 \\
\hline & 0.008 & 0.02 & 0.012 \\
\hline
\end{tabular}




\section{Note}

Standard errors in parentheses, $* \star \star p<0.01, * \star p<0.05, * p<0.1$

However, in this kind of model specification, Aid $_{\mathrm{it}-1}$ is correlated with the fixed effects in the error term $\varepsilon_{\mathrm{it}}$ which gives rise to a 'dynamic panel bias' (Nickell,1981).This phenomenon could inflate the co-efficient estimate for the lagged aid variable by attributing predictive power to it that actually belongs to the country's fixed effects. Thus, it could reduce the impact of one-year's shock on a country's apparent fixed effects and thereby diminishing endogeneity problem too. To solve these problems, the system generalized method of moments (GMM) estimation developed by Blundell and Bond (1998) has been used. GMM solves the endogenous bias problem that relates to the inclusion of the lagged dependent variables and instrumental variables for other possible endogenous variables. It also addresses the independent variables that are not exogenous, as well as the fixed effects, heteroskedasticity and autocorrelation within countries. The estimation has been run by building a set of two equations, including the original equation in Eq. 2 and the transformed equation or the differenced equation, as specified in Eq. 6.

\section{Recipient needs GMM model}

In $(\Delta \text { Net ODA received })_{i t}=\rho\left(\Delta\right.$ Aid $\left._{i t-1}\right)+\beta_{1}(\Delta \text { Coal Prod })_{i t}+\beta_{2}(\Delta \text { Coal Consumption })_{i t}+\beta_{3}\left(\Delta \mathrm{CO}_{2}\right.$

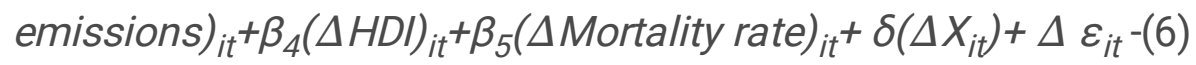

The lagged difference in the endogenous variables is used as an instrument for the original equation, and the lagged levels of the endogenous variables are used as an instrument for the transformed equation. The results of the GMM model are as follows. Across all the three models (1), (2) \& (3) - all of the variables including coal production, coal consumption, $\mathrm{CO}_{2}$ emissions, $\mathrm{HDI}$, Mortality rate, Population and GDP were coming out to be significant but having very small beta co-efficient values. The table is listed in the appendix(....). Hence, the predictive power of these variables in the GMM model is very limited.

Hence, after looking at the results of all these three models' regressions, it could be seen that in the FE regression, all of the specifications show a moderate fitness to the regression lines, with R-squared values between 0.38 and 0.4 . But in the lagged dependent variable model, the R-square of the model specifications has reduced, which to a certain level explains the fact that aid-received by a country in a specific year is not greatly influenced by its previous year aid allocation. Also, in all the three model estimations above (i.e, FE, lagged dependent variable model \& GMM); variables such as coal production, coal consumption, $\mathrm{CO}_{2}$ emissions \& HDI were significant across models (1), (2) and (3) throughout. All these variables other than HDI had a negative co-efficient sign, which implies that as the receptor countries are lowering their rates of $\mathrm{CO}_{2}$ emissions, Coal production \& Coal consumption; the aid they receive from the donor nations is rising. Hence, the developing nations are demanding more aid for being more cleaner compared to other nations. The evidence from HDI also supports this fact that, better the country is doing in terms of its $\mathrm{HDI}$, higher is the amount of aid they receive for sustainable initiatives. 
Variables like mortality rate, GDP and population did not turn out to be significant in the FE and the lagged dependent model. Though they were significant in the GMM model, their coefficients had very little explanatory power.

Overall, the recipient countries are receiving more aid as they move towards performing better in terms of $\mathrm{HDI}$, and also being more cleaner through lowering their coal consumption, production \& $\mathrm{CO}_{2}$ emissions.

\section{Model lii}

\subsection{Good Governance Model of the Recipient Country}

The third model is based on the recipient country's governance level, where the donors favor countries that can use development aid most effectively. This model is important because if aid goes to a country that has a low capacity or commitment to aid implementation, then the aid will not achieve its best possible outcome. Thus, this model is based on a cost-effectiveness perspective. For example, the intensive aid program of the Education for All Fast-Track Initiative (EFA-TFI), which was launched in 2002, was one very good example in which the good governance of the recipient country was an important criterion for providing aid. According to this scheme, a recipient country has to demonstrate a serious commitment and ability to achieve universal primary education by presenting good policies and coordination plans, for it to receive the aid (Sumida, 2017).

Several other studies have clearly found an association between good governance and aid allocation. Alesina and Dollar (2000), examined the historical change in the relation between aid and governance level as measured by the democracy and civil liberties index of freedom house. They found an increasing trend from 1970 to 1994 that aid donors favored democratized countries. Continuing with this, Claessens et al. (2009) studied the time period 1970-2004 and presented a significant relationship between the CPIA (Country Policy and Institutional Assessment) scores and the development aid. Berthelemy (2006), in his study also found a significant relationship between development aid and two government proxies of the level of civil liberties \& political freedom evaluation which is given by Freedom House. He also reveals that the most significant trading partners provide aid to alleviate some recipients' needs. From the above evidence, it is clear that donor governments prefer to give aid to countries in which the expected outcome is more likely to be realized than to countries that do not know whether they can achieve the expected outcome. Hence, good governance has become an important aspect in the aid allocation decisions of the donors since 1990's.

\subsection{Variables used in the Regression Analysis}

Following the previous literature, the variables described below have been used for the current model.

\section{Dependent variable}

Net ODA Received (log) 
Since this model is the good governance model, Official Development Assistance received is considered as our $\mathrm{Y}$ variable. The rationale for using this variable is to understand how the aid received by the recipient country is being affected by the level of good governance in their country.

\section{Independent variables}

Political Rights, Civil Liberties, Freedom Status and Democracy

As in the other models mentioned above coal production, coal consumption \& $\mathrm{CO}_{2}$ Emissions of 23 developing nations are considered along with their good governance indicators as independent variables. The idea is to understand how the aid received for sustainable purposes by the recipient country is getting influenced by the state of governance in the country. Table 8.2.1 lists the variables used in the donors self interests models' regression along with their definition and sources.

Table 8.2.1

Good Governance model of the Recipient country: Variables and Sources

\begin{tabular}{|c|c|c|}
\hline VARIABLES & DEFINITION & SOURCES \\
\hline $\begin{array}{l}\text { Aid Given } \\
\text { i)Net ODA Received }\end{array}$ & $\begin{array}{l}\text { Government aid received for economic } \\
\text { development \& welfare (MN_USD\$) }\end{array}$ & World bank \\
\hline Good Governance & \multirow{2}{*}{$\begin{array}{l}\text { Score from 1(high) to 7(low) } \\
\text { Based on PR and CL: 1-2.5(Free), 3.5-5(Partly free), } \\
\text { 5.5-7(Not free) }\end{array}$} & \multirow{3}{*}{$\begin{array}{l}\text { Freedom House } \\
\text { Freedom House } \\
\text { The Economist Website }\end{array}$} \\
\hline i) Political Rights \& & & \\
\hline $\begin{array}{l}\text { ii) Freedom Status } \\
\text { iii) Democracy }\end{array}$ & $\begin{array}{l}\text { Regime by type Authoritarian, Flawed democracy, } \\
\text { Hybrid Regime \& Full democracy }\end{array}$ & \\
\hline $\begin{array}{l}\text { Sustainable } \\
\text { indicators }\end{array}$ & & $\begin{array}{l}\text { International Energy } \\
\text { Statistics }\end{array}$ \\
\hline i) Coal Production & \multirow[t]{3}{*}{ Annual $\mathrm{CO}_{2}$ emissions per country } & $\begin{array}{l}\text { B.P Statistical Review } \\
\text { of Global Energy }\end{array}$ \\
\hline Consumption & & \multirow[t]{2}{*}{$\begin{array}{l}\text { Global Carbon } \\
\text { Project,2017 }\end{array}$} \\
\hline iii) CO2 Emissions & & \\
\hline Control Variables & GDP Per Capita, current US\$ & World Bank \\
\hline i)GDP Per Capita & Population, total( in thousands) & World Bank \\
\hline ii) Population & & \\
\hline
\end{tabular}

The Net ODA received data are drawn from the World Bank development indicators database. Official development assistance (ODA) is defined as government aid designed to promote economic development and welfare of developing countries. Loans and credits for military purposes are excluded. Aid may be 
provided bilaterally, from donor to recipient, or channelled through a multilateral development agency such as the United Nations or the World bank. Net Official Development Assistance (ODA) consists of disbursements of loans made on concessional terms ( net of repayments of principal) and grants by official agencies of the members of the Development Assistance Committee (DAC), by multilateral institutions, and by non-DAC countries to promote economic development and welfare in countries and territories in the DAC list of ODA recipients. It includes loans with a grant element of at least $25 \%$ (calculated at a rate of discount 10\%). Data are in million US dollars. The data period spans for 25 years beginning in 1992 until the most recent collection of data in 2016. Over this period, the data set covers 23 aid-recipient countries in total, excluding a few, due to data constraints.

The level of good governance of a country, are captured by its political rights \& civil liberties. Political rights represent the degree of freedom in the country based on a world survey that examines political conditions, such as electoral process, political pluralism and participation, the functioning of government, and the degree of freedom of expression and belief. Political rights are measured on a one to seven scale, with one representing the highest level of freedom and seven representing the lowest level of freedom. Based on Political Rights \& Civil liberties in a country, its freedom status is decided as mentioned in the table. The variable democracy is a classification into four categories based on the country's regime; i.e, authoritarian, flawed democracy, hybrid regime and full democracy. The model also includes our sustainability indicators i.e, coal production, coal consumption \& $\mathrm{CO}_{2}$ emissions of the receptor countries to see if the aid received by the countries is being affected not only by its governance indicators, but also because of the performance of these variables.

Following the previous literature, the study also accounts for the effect of potential confounding variables. This process is necessary to observe the effect of the included variables by ensuring that their remaining effect is not due to omitted variable bias. As informed by the previous literature, natural logarithm of GDP per capita and total population were included. Both data are drawn from the World Development Indicators.

\subsection{Model Specification}

Since the data used in this study is panel data that has two dimensions, namely receptor country and time, firstly, the benchmark fixed effects model includes country-fixed effects to control for the unobserved country-specific and time invariant factor determinants of aid. Thus the specification shown in Eq. 7 includes two groups of explanatory variables and control variables.

\section{Good Governance of the Receptor Countries: Random effects Model}

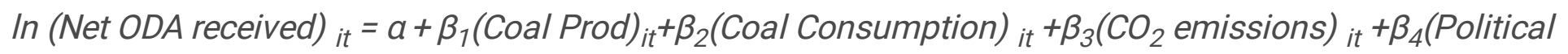
rights) ${ }_{i t}+\beta_{5}$ (Civil Liberties) $_{i t}+\beta_{6}$ (Freedom Status) $_{i t}+\beta_{7}$ (Democracy) $_{i t}+\delta X_{i t}+u_{i}+\varepsilon_{i t}-(7)$

where the dependent variable $\mathrm{Aid}_{\mathrm{it}}$ is the amount of ODA received by the recipient country $i$ in period $t$. The three variables coal production, coal consumption and $\mathrm{CO}_{2}$ emissions represent our sustainable 
variables of receptor country $i$ in period $t$. These three variables exhibited strong multi-collinearity and were thus included one by one in the estimation. Therefore these three variables were estimated separately in three different models. For the other variables, variance inflation factors (VIF's) were calculated to check whether multi-collinearity caused a problem in the estimation, but could not find any evidence that suggests that it seriously affected the estimation results. Variables like Political Rights, Civil Liberties, freedom status etc. capture the receptor country's governance level in country $i$ for period $t . X_{i t}$ is the control variables of GDP Per capita and total population of country $i$ in period $t$. The term $\mathrm{u}_{\mathrm{i}}$ is the country random effects and denotes the time-invariant differences in providing aid across the donor countries and $\varepsilon_{\text {it }}$ is the error term in the model.

After performing the Hausman test for fixed effects and random effects, the null hypothesis of random effects model is appropriate has failed to be rejected and hence random effects estimation has been used in this model and its results are as given below in Table 8.3.1 
Table 8.3.1

Relation between Net ODA received \& Good Governance of the Receptor countries: RE regression

\begin{tabular}{|c|c|c|c|}
\hline & \multicolumn{3}{|c|}{ Random effects Estimation } \\
\hline & \multicolumn{3}{|c|}{ Coal Production Coal Consumption $\mathrm{CO}_{2}$ emissions } \\
\hline & \multicolumn{3}{|l|}{ (1) (2) (3) } \\
\hline Good Governance Indicators & -0.01 & -0.005 & -0.003 \\
\hline Political freedom & $(0.065)$ & $(0.065)$ & $(0.065)$ \\
\hline Civil Liberties & -0.085 & -0.083 & -0.085 \\
\hline Democracy level1(authoritarian) & $(0.075)$ & $(0.075)$ & $(0.075)$ \\
\hline Democracy level 2(Flawed democracy) & $-5.14^{\star \star}$ & $-5.18^{\star \star}$ & $-5.14^{\star \star}$ \\
\hline Freedom Status 1(F) & (2.33) & (2.34) & (2.32) \\
\hline Freedom Status 2(NF) & -0.989 & -0.95 & -0.94 \\
\hline Freedom Status 3 (PF) & $(2.20)$ & $(2.21)$ & $(2.19)$ \\
\hline Sustainable variables & 0.228 & 0.201 & 0.236 \\
\hline Coal Production & $(0.819)$ & $(0.82)$ & $(0.823)$ \\
\hline Coal Consumption & 0.573 & 0.565 & 0.590 \\
\hline $\mathrm{CO}_{2}$ Emissions & $(0.80)$ & $(0.803)$ & $(0.803)$ \\
\hline Control Variables & 0.43 & 0.414 & 0.439 \\
\hline GDP Per Capita (log) & $(0.79)$ & $(0.793)$ & $(0.793)$ \\
\hline Population (log) & $-0.0007^{\star \star \star}$ & $-0.001^{\star \star \star}$ & $-0.0002^{\star \star \star}$ \\
\hline Constant & $(0.0002)$ & $(0.0004)$ & $(0.00009)$ \\
\hline Observations & $0.209^{\star \star}$ & $0.181^{\star *}$ & $0.194^{\star \star}$ \\
\hline R-squared & $(0.09)$ & $(0.090)$ & $(0.09)$ \\
\hline & 0.655 & 0.705 & 0.733 \\
\hline & $(0.433)$ & $(0.435)$ & $(0.432)$ \\
\hline & 7.08 & 6.34 & 5.74 \\
\hline & $(7.85)$ & (7.89) & $(7.84)$ \\
\hline & 543 & 543 & 543 \\
\hline & 0.22 & 0.23 & 0.23 \\
\hline
\end{tabular}




\section{Note}

Standard errors in parentheses, $* \star \star p<0.01, * \star p<0.05, * p<0.1$

Second, the study also included lagged dependent variable in the analysis performed because donors' tend to allocate aid to a country that has already received a certain amount of aid, rather to a country they do not know about; thus it is hypothesized that the aid flows in the current period tend to be related to the previous periods' aid allocation. This new specification including lagged version of the dependent variable as one of the independent variable is given in Eq. 8.

\section{Good Governance model of receptor countries: Lagged Dependent variable Model}

In (Net ODA received) ${ }_{i t}=a+\rho$ Aid $_{t-} 1+\beta 1(\text { Coal Prod })_{i t}+\beta_{2}$ (Coal Consumption) ${ }_{i t}+\beta_{3}\left(\mathrm{CO}_{2}\right.$ emissions) ${ }_{\text {it }}$ $+\beta_{4}$ (Political rights) $_{i t}+\beta_{5}$ (Civil Liberties) $_{i t}+\beta_{6}$ (Freedom Status) $_{i t}+\beta_{7}(\text { Democracy) })_{i t}+\delta X_{i t}+u_{i}+\varepsilon_{i t}-(8)$

The results of the model are presented in Table 8.3.2 
Table 8.3.2

Relation between Net ODA received \& Good governance of the receptor countries: Lagged dependent variable model, RE regression

Lagged Dependent Variable Model: RE Estimation

Coal Production Coal Consumption. $\mathrm{CO}_{2}$ emissions

(1) (2) (3) 


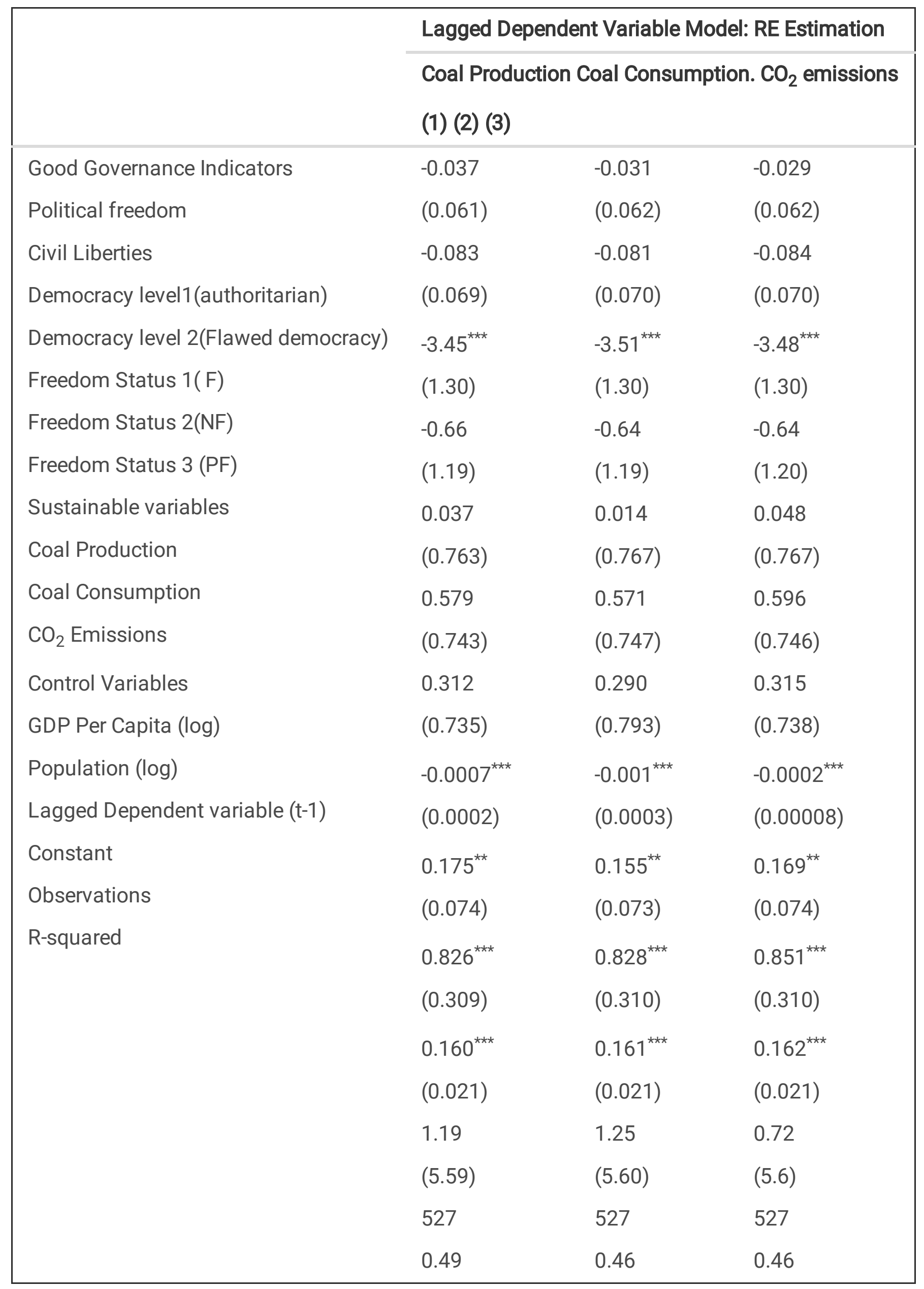




\section{Note}

Standard errors in parentheses, ${ }^{\star \star *} p<0.01,{ }^{\star *} p<0.05,{ }^{*} p<0.1$

However, in this kind of model specification, Aid $_{\mathrm{it}-1}$ is correlated with the random effects in the error term $\varepsilon_{\text {it }}$ which gives rise to a 'dynamic panel bias' (Nickell, 1981). This phenomenon could inflate the coefficient estimate for the lagged aid variable by attributing predictive power to it that actually belongs to the country's random effects. Thus, it could reduce the impact of one-year's shock on a country's apparent random effects and thereby diminishing endogeneity problem too. To solve these problems, the system generalized method of moments (GMM) estimation developed by Blundell and Bond (1998) has been used. GMM solves the endogenous bias problem that relates to the inclusion of the lagged dependent variables and instrumental variables for other possible endogenous variables. It also addresses the independent variables that are not exogenous, as well as the random effects, heteroskedasticity and autocorrelation within countries. The estimation has been run by building a set of two equations, including the original equation in Eq. 8 and the transformed equation or the differenced equation, as specified in Eq. 9.

\section{Good Governance of Receptor Countries: GMM Model}

$\ln (\Delta \text { Net ODA received })_{i t}=\rho\left(\Delta\right.$ Aid $\left._{i t-1}\right)+\beta_{1}(\Delta \text { Coal Prod })_{i t}+\beta_{2}(\Delta \text { Coal Consumption })_{i t}+\beta_{3}(\Delta$ Co 2

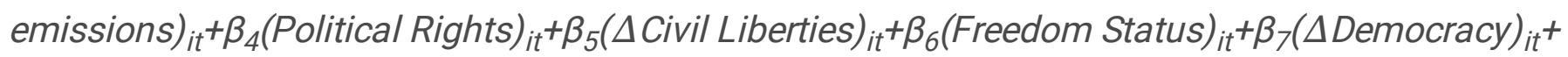
$\delta\left(\Delta X_{i t}\right)+\Delta \varepsilon_{i t}-(9)$

The lagged difference in the endogenous variables is used as an instrument for the original equation, and the lagged levels of the endogenous variables are used as an instrument for the transformed equation. The results of the system GMM specification are presented below in Table 8.3.3. 
Table 8.3.3

Relation between Net ODA received \& Good governance of the receptor countries: GMM Model

\begin{tabular}{|c|c|c|c|}
\hline & \multicolumn{3}{|c|}{ GMM Estimation } \\
\hline & $\begin{array}{l}\text { Coal Prod } \\
(1)(2)(3)\end{array}$ & Coal Cons & n $\mathrm{CO}_{2}$ emissions \\
\hline Good Governance Indicators & -0.038 & -0.029 & -0.035 \\
\hline Political freedom & $(0.069)$ & $(0.069)$ & $(0.069)$ \\
\hline Civil Liberties & -0.036 & -0.039 & -0.037 \\
\hline Democracy level1(authoritarian) & $(0.080)$ & $(0.080)$ & $(0.080)$ \\
\hline Democracy level 2 (Flawed democracy) & - & - & - \\
\hline Freedom Status 1 (F) & - & - & - \\
\hline Freedom Status 2 (NF) & 0.099 & 0.075 & 0.081 \\
\hline Freedom Status 3 (PF) & $(0.571)$ & $(0.571)$ & $(0.572)$ \\
\hline Sustainable variables & 0.422 & 0.372 & 0.391 \\
\hline Coal Production & $(0.582)$ & $(0.582)$ & $(0.582)$ \\
\hline Coal Consumption & 0.194 & 0.166 & 0.172 \\
\hline $\mathrm{CO}_{2}$ Emissions & $(0.536)$ & $(0.536)$ & $(0.537)$ \\
\hline Control Variables & $-0.001^{\star \star \star}$ & -0.0007 & $-0.0003^{\star \star \star}$ \\
\hline GDP Per Capita (log) & $(0.0003)$ & $(0.0005)$ & $(0.0001)$ \\
\hline Population (log) & $0.680^{\star \star \star}$ & $0.60^{\star *}$ & $0.660^{\star \star \star}$ \\
\hline Constant & $(0.10)$ & $(0.104)$ & $(0.106)$ \\
\hline Observations & $-1.62^{\star \star \star}$ & $-1.72^{\star \star \star}$ & $-1.63^{\star \star \star}$ \\
\hline \multirow[t]{5}{*}{ R-squared } & $(0.60)$ & $(0.60)$ & $(0.60)$ \\
\hline & $47.81^{\star \star \star}$ & $50.41^{\star \star \star}$ & $48.25^{\star \star \star}$ \\
\hline & $(10.46)$ & $(10.48)$ & $(10.46)$ \\
\hline & 476 & 476 & 476 \\
\hline & 0.38 & 0.42 & 0.35 \\
\hline
\end{tabular}

Note

Standard errors in parentheses, ${ }^{\star * \star} p<0.01,{ }^{\star *} p<0.05,{ }^{*} p<0.1$ 
Tables 8.3.1, 8.3.2 \& 8.3.3 show the results of association of good governance variables with log Net ODA received. In the RE regression, all of the specifications show a less moderate fitness to the regression lines, with R-squared values between 0.2 and 0.3. In contrast, the lagged dependent variable model shows has a moderate fit, with R-squared values from 0.45 to 0.5 . In all the three estimations above, Coal production, $\mathrm{CO}_{2}$ emissions \& GDP per-capita have been significant throughout across specifications (1), (2) and (3). This is in support of the recipients needs model, which suggested that the aid received by a country increases as they tend to become more cleaner (in terms of production \& emission) and also as a country performs better in terms of GDP, their aid for sustainable initiatives is seeing a rise. In the first two specifications, the democracy 1 variable (which signifies a authoritarian regime) is significant with a negative sign attached to it. This implies the fact that as countries tend to move far away from a democratic rule, the aid they receive reduces. Hence, more democratic a country is, more aid it receives for its sustainable initiatives too.

A similar kind of analysis was done for the donor nations, to observe whether good governance in the donor countries influenced their aid allocation decisions. Here, in this model; Net ODA given was considered as the $Y$ variable, and the remaining variables still remain the same. The results did not reveal a significant relationship in any of their variables, other than GDP and population (partially). This implies that the governance in the donor countries is not a key factor in explaining the aid allocation decisions of the donor countries.

\section{Model Iv}

\subsection{Fragile State Priority Model}

The fourth model is mostly the opposite of the third motivation. According to the fragile State priority model, donors provide their support to the countries that are more affected by conflict and weak political institutions, which are generally called fragile states. It has been argues that there are mixed motivations for aiding fragile states because fragile states are very likely to have a high level of unsatisfied needs. But, however, Addison et al(2016), argued that by ensuring a post-conflict reconstruction that sustains peace, new markets can be developed for future trade, which can also be considered a geopolitical priority for a donor country that can be regarded as acting in its self-interest. It is however difficult to separate these hidden motivations and therefore the rationale for the priority to fragile states must be examined separately from the three other rationales mentioned above. Anyhow, there is no solid definition of a fragile state, but is generally characterized as a low-income country with weak state capacity or weak state legitimacy that leaves citizens vulnerable to a range of shocks. Turrent and Oketch(2009) used the CPIA index to group 52 low income countries into fragile and non-fragile states and showed that donors provide less educational aid to fragile states than the non-fragile states. However, not sufficient literature is present to provide support to this framework.

\subsection{Variables used in the Regression Analysis}


Following the previous literature, the variables described below have been used for the current study along with our sustainable indicators.

\section{Dependent variable}

Net ODA Received (log)

Since this model is fragile state priority model, Official Development Assistance received is considered as $Y$ variable. The rationale for using this variable is to understand how the receptor country's aid received is being affected because of their state's fragility.

\section{Independent variables}

State fragility index \& armed conflict

As in the other models mentioned above coal production, coal consumption \& $\mathrm{CO}_{2}$ Emissions of 23 developing nations are considered along with their state fragility index \& armed conflict as independent variables. The idea is to understand how the aid received for sustainable purposes changes as the nations' fragility changes.

Table 9.2.1 lists the variables used in the Fragile State Priority model regression along with their definition and sources. 
Table 9.2.1

Fragile State Priority model variables and sources

\begin{tabular}{|c|c|c|}
\hline VARIABLES & DEFINITION & SOURCES \\
\hline Aid Given & \multirow{2}{*}{$\begin{array}{l}\text { Government aid received for economic development } \\
\& \text { welfare (MN_USDS) }\end{array}$} & \multirow[t]{2}{*}{ World bank } \\
\hline $\begin{array}{l}\text { i) Net ODA } \\
\text { received }\end{array}$ & & \\
\hline
\end{tabular}
Fragile State Score from 0 (no fragility) to 25 (high fragility)
Priority
i) State
Total armed conflicts yearly
Centre for Systemic Peace
Fund for Peace
Fragility Index

ii)Armed

Conflict

\section{Sustainable indicators}

i) Coal

Production

ii) Coal

Consumption

iii) $\mathrm{CO} 2$

Emissions

\section{Control}

Variables

i)GDP Per

Capita

ii) Population
Coal Production by country(mn_ton)

Coal Consumption by country(mn_ton)

Annual CO2 emissions per country

GDP Per Capita, current US\$

Population, total( in thousands)
International Energy

Statistics

B.P Statistical Review of Global Energy

Global Carbon

Project,2017

The Net ODA received data are drawn from the World Bank development indicators database. Official development assistance (ODA) is defined as government aid designed to promote economic development and welfare of developing countries. Loans and credits for military purposes are excluded. Aid may be provided bilaterally, from donor to recipient, or channelled through a multilateral development agency such as the United Nations or the World bank. Net Official Development Assistance (ODA) consists of disbursements of loans made on concessional terms (net of repayments of principal) and grants by official agencies of the members of the Development Assistance Committee (DAC), by multilateral institutions, and by non-DAC countries to promote economic development and welfare in countries and territories in the DAC list of ODA recipients. It includes loans with a grant element of at least $25 \%$ (calculated at a rate of discount of $10 \%$ ). Data are in million US dollars.

The data period spans for 16 years beginning in 1995 until the collection of data in 2010. Over this period, the data set covers 23 aid-recipient countries in total, excluding a few due to data constraints. 
The measurement of a fragile state is captured by the two variables of state fragility index and armed conflict. The state fragility index is a combined index that is produced by the Centre of Systemic Peace and is measured based on the following four performance dimensions: security(total residual war and state repression); political(regime/governance stability and regime/governance inclusion); economic(GDP per capita and share of export trade in manufactured goods); and social(human development indicator (HDI) and infant mortality rate). The index ranges from 0 for no fragility to 25 for extreme fragility. This model also includes our sustainability indicators i.e, coal production, coal consumption $\& \mathrm{CO}_{2}$ emissions to see if the aid received by the countries is being affected not only by its fragility, but also because of the performance of these variables.

Following the previous literature, the study also accounts for the effect of potential confounding variables. This process is necessary to observe the effect of the included variables by ensuring that their remaining effect is not due to omitted variable bias. As informed by the previous literature, natural logarithm of GDP per capita and total population were included. Both data are drawn from the World Development Indicators.

\subsection{Model Specification}

Since the data used in this study is panel data that has two dimensions, namely receptor country and time, firstly, the benchmark fixed effects model includes country-fixed effects to control for the unobserved country- specific and time invariant factor determinants of aid. Thus the specification shown in Eq. 10 includes two groups of explanatory variables and control variables.

\section{Fragile State Priority Fixed effects Model}

In (Net ODA received) ${ }_{i t}=a+\beta_{1}$ (Coal Production) $)_{i t}+\beta_{2}$ (Coal Consumption) ${ }_{i t}+\beta_{3}\left(\mathrm{CO}_{2}\right.$ emissions) it

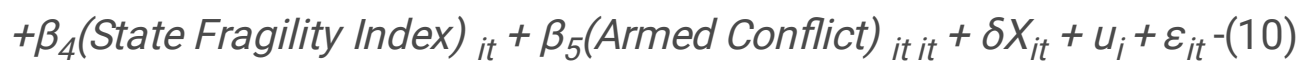

where the dependent variable $\mathrm{Aid}_{\mathrm{it}}$ is the amount of ODA received by the recipient country $i$ in period $t$. The three variables coal production, coal consumption and $\mathrm{CO}_{2}$ emissions represent our sustainable variables of recipient country $i$ in period $t$. Similar to the previous model, these three variables exhibited strong multi-collinearity and were thus included one by one in the estimation. Therefore these three variables were estimated separately in three different models. For the other variables, variance inflation factors (VIF's) were calculated to check whether multi-collinearity caused a problem in the estimation, but could not find any evidence that suggests that it seriously affected the estimation results. Variables like State fragility index and armed conflict capture the recipient country's fragility in country $i$ for period $t$. $X_{i t}$ is the control variables of GDP Per capita and total population of country $i$ in period $t$. The term $\mathrm{u}_{\mathrm{i}}$ is the country fixed effects and denotes the time-invariant differences in receiving aid across the recipient countries and $\varepsilon_{i t}$ is the error term in the model.

Similar to the other models, after performing the Hausman test for fixed effects and random effects, the null hypothesis of random effects model is appropriate was rejected and hence fixed effects estimation 
has been used in this model and its results are as given below in Table 9.3.1

Table 9.3.1

Relation between Net ODA received \& State fragility: FE regression

\begin{tabular}{|c|c|c|c|}
\hline & \multicolumn{3}{|c|}{ Fixed effects Estimation } \\
\hline & \multicolumn{3}{|c|}{ Coal Production Coal Consumption $\mathrm{CO}_{2}$ emissions } \\
\hline & \multicolumn{3}{|l|}{ (1) (2) (3) } \\
\hline Fragile State Priority Model & 0.043 & 0.045 & 0.044 \\
\hline State Fragility Index & $(0.029)$ & $(0.029)$ & $(0.029)$ \\
\hline Armed Conflict & 0.040 & 0.041 & 0.042 \\
\hline Sustainability indicators & $(0.031)$ & $(0.031)$ & $(0.031)$ \\
\hline Coal Production & $-0.0006^{* \star *}$ & $-0.0011^{\star \star \star}$ & $-0.0002^{\star \star \star}$ \\
\hline Coal Consumption & $(0.0001)$ & $(0.0003)$ & $(0.00008)$ \\
\hline $\mathrm{CO}_{2}$ Emissions & $0.39^{\star \star \star}$ & $0.37^{\star \star \star}$ & $0.391^{\star \star \star}$ \\
\hline Control Variables & $(0.10)$ & $(0.10)$ & $(0.109)$ \\
\hline GDP Per Capita (log) & 0.99 & 1.04 & 1.04 \\
\hline Population (log) & $(0.73)$ & $(0.73)$ & $(0.73)$ \\
\hline Constant & -15.44 & -16.30 & -16.4 \\
\hline Observations & $(13.07)$ & $(13.06)$ & (13.02) \\
\hline \multirow[t]{2}{*}{ R-squared } & 355 & 355 & 355 \\
\hline & 0.25 & 0.27 & 0.279 \\
\hline
\end{tabular}

\section{Note}

Standard errors in parentheses, $* \star \star p<0.01, * \star p<0.05, * p<0.1$

Second, the study also included lagged dependent variable in the analysis performed because donors' tend to allocate aid to a country that has already received a certain amount of aid, rather to a country they do not know about; thus it is hypothesized that the aid flows in the current period tend to be related to the previous periods' aid allocation. This new specification including lagged version of the dependent variable as one of the independent variable is given in Eq. 11 .

\section{Fragile State Priority Lagged Dependent Variable Model}

In (Net ODA received) it $=a+\rho$ Aid $_{t^{-}} 1+\beta_{1}(\text { Coal Production })_{i t}+\beta_{2}$ (Coal Consumption) ${ }_{i t}+\beta_{3}\left(\mathrm{CO}_{2}\right.$ emissions $)$

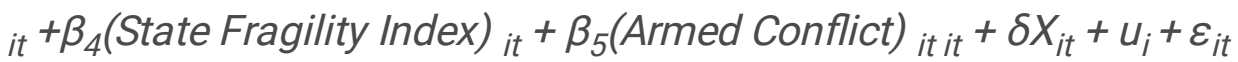


The results of the model are presented in Table 9.3.2

Table 9.3.2

Relation between Net ODA received \& State fragility: Lagged dependent variable regression

\begin{tabular}{|c|c|c|c|}
\hline & \multicolumn{3}{|c|}{ Lagged Dependent Variable : Fixed effects Estimatior } \\
\hline & $\begin{array}{l}\text { Coal Produ } \\
\text { (1) (2) (3) }\end{array}$ & oal Consun & $\mathrm{O}_{2}$ emissions \\
\hline Fragile State Priority Model & 0.040 & 0.042 & 0.041 \\
\hline State Fragility Index & $(0.026)$ & $(0.026)$ & $(0.026)$ \\
\hline Armed Conflict & 0.024 & 0.025 & 0.026 \\
\hline Sustainability indicators & $(0.029)$ & $(0.029)$ & $(0.029)$ \\
\hline Coal Production & $-0.0005^{\star \star \star}$ & $-0.0009^{* \star \star}$ & $-0.0002^{\star \star \star}$ \\
\hline Coal Consumption & $(0.0001)$ & $(0.0003)$ & $(0.00007)$ \\
\hline $\mathrm{CO}_{2}$ Emissions & $0.256^{* *}$ & $0.244^{\star *}$ & $0.254^{\star \star}$ \\
\hline Control Variables & $(0.102)$ & $(0.102)$ & $(0.103)$ \\
\hline GDP Per Capita (log) & $1.54^{\star \star}$ & $1.58^{\star *}$ & $1.59^{\star \star}$ \\
\hline Population (log) & $(0.681)$ & $(0.681)$ & $(0.679)$ \\
\hline Lagged Dependent variable(t-1) & $0.273^{\star \star \star}$ & $0.275^{\star \star \star}$ & $0.273^{\star \star \star}$ \\
\hline $\begin{array}{l}\text { Constant } \\
\text { Observations }\end{array}$ & $(0.044)$ & $(0.044)$ & $(0.044)$ \\
\hline R-squared & $-25.93^{\star \star}$ & $-26.70^{\star \star}$ & $-26.9^{\star \star}$ \\
\hline & (12.16) & (12.15) & (12.12) \\
\hline & 347 & 347 & 347 \\
\hline & 0.453 & 0.456 & 0.46 \\
\hline
\end{tabular}

\section{Note}

Standard errors in parentheses, $* \star \star p<0.01, * \star p<0.05, * p<0.1$

However, in this kind of model specification, Aid $_{\mathrm{it}-1}$ is correlated with the fixed effects in the error term $\varepsilon_{\mathrm{it}}$ which gives rise to a 'dynamic panel bias' (Nickell,1981). This phenomenon could inflate the co-efficient estimate for the lagged aid variable by attributing predictive power to it that actually belongs to the country's fixed effects. Thus, it could reduce the impact of one-year's shock on a country's apparent fixed 
effects and thereby diminishing endogeneity problem too. To solve these problems, the system generalized method of moments (GMM) estimation developed by Blundell and Bond (1998) has been used. GMM solves the endogenous bias problem that relates to the inclusion of the lagged dependent variables and instrumental variables for other possible endogenous variables. It also addresses the independent variables that are not exogenous, as well as the fixed effects, heteroskedasticity and autocorrelation within countries. The estimation has been run by building a set of two equations, including the original equation in Eq. 2 and the transformed equation or the differenced equation, as specified in Eq. 12.

\section{Fragile State Priority GMM Model}

In $(\Delta \text { Net ODA received })_{i t}=\rho\left(\Delta\right.$ Aid $\left._{i t-1}\right)+\beta_{1}(\Delta \text { Coal Prod })_{i t}+\beta_{2}(\Delta \text { Coal Consumption })_{i t}+\beta_{3}(\Delta$ Co 2 emissions) $)_{i t}+\beta_{4}(\Delta \text { State fragility Index })_{i t}+\beta_{5}(\Delta \text { Armed Conflict })_{i t}+\delta\left(\Delta X_{i t}\right)+\Delta \varepsilon_{i t}-(12)$

The lagged difference in the endogenous variables is used as an instrument for the original equation, and the lagged levels of the endogenous variables are used as an instrument for the transformed equation. The results of the system GMM specification are presented below in Table 9.3.3. 
Table 9.3.3

Relation between Net ODA received \& State fragility: GMM Estimation

\begin{tabular}{|c|c|c|c|}
\hline & \multicolumn{3}{|c|}{ GMM Estimation } \\
\hline & \multicolumn{3}{|c|}{ Coal Production Coal Consumption $\mathrm{CO}_{2}$ emissions } \\
\hline & \multicolumn{3}{|c|}{ (1) (2) (3) } \\
\hline Fragile State Priority Model & $0.129^{\star \star \star}$ & $0.138^{\star \star \star}$ & $0.131^{\star \star \star}$ \\
\hline State Fragility Index & $(0.037)$ & $(0.037)$ & $(0.037)$ \\
\hline Armed Conflict & -0.002 & 0.004 & -0.001 \\
\hline Sustainability indicators & $(0.041)$ & $(0.041)$ & $(0.041)$ \\
\hline Coal Production & $-0.0006^{\star *}$ & -0.0006 & $-0.0002^{\star \star}$ \\
\hline Coal Consumption & $(0.0002)$ & $(0.0004)$ & $(0.0001)$ \\
\hline $\mathrm{CO}_{2}$ Emissions & $0.422^{\star \star \star}$ & $0.394^{\star \star \star}$ & $0.419^{\star \star \star}$ \\
\hline Control Variables & $(0.118)$ & $(0.118)$ & $(0.118)$ \\
\hline GDP Per Capita (log) & $1.68^{\star \star}$ & $1.74^{\star \star}$ & $1.75^{\star \star}$ \\
\hline & $(0.918)$ & $(0.919)$ & $(0.917)$ \\
\hline & $-29.23^{\star \star}$ & $-30.23^{\star \star}$ & $-30.49^{\star \star}$ \\
\hline Ubservations & $(16.45)$ & $(16.47)$ & (16.43) \\
\hline resquarea & 321 & 321 & 321 \\
\hline & 0.256 & 0.35 & 0.38 \\
\hline
\end{tabular}

\section{Note}

Standard errors in parentheses, $* \star * p<0.01, * \star p<0.05,{ }^{*} p<0.1$

Tables 9.3.1, 9.3.2 \& 9.3.3 show the results of association of fragility of a receptor country and the log Net ODA received. In the FE regression, all of the specifications show a less moderate fitness to the regression lines, with R-squared values between 0.25 and 0.3. In contrast, the lagged dependent variable model shows has a moderate fit, with R-squared values from 0.45 to 0.5 . In all the three estimations above (FE, lagged dependent variable model $\& \mathrm{GMM}$ ), variables such as Coal production, $\mathrm{CO}_{2}$ emissions and GDP per-capita have been significant throughout across models (1), (2) \& (3). Coal consumption was significant in the FE and lagged dependent variable specification, but its significance disappears in the GMM model. GDP per-capita has a positive co-efficient in all the models conveying the fact that as the GDP of a recipient country is increasing, the aid they receive for sustainable initiatives is increasing. This result reveals the idea that donors are not providing aid to more fragile states, rather increasing their aid 
allocation to countries as they become less fragile. This evidence is also supported by the fact that; as both Coal production and $\mathrm{CO}_{2}$ emissions are declining, the aid received by a country is rising. This is very similar to the results in the recipients' needs models, where the receptor country was rewarded better for being more cleaner. The fragility variables of SFI and armed conflict did not show any significance across the first two models. In conclusion, it can be said that donor's are allocating more aid for sustainable purposes to a country which is less fragile in nature.

\section{Conclusion}

This study explored donors decision making rationales in sustainable aid allocation by examining the relationship between sustainable aid and the four rational choice models of donors' self-interests, recipient's needs, good governance and fragile states. The study found statistical evidence in three of its models namely donors' self-interests, recipient's needs \& good governance. In the donors' self-interests model, a strong association was found with the government expenditure and population, which reveals the point that donor nations increase their provision of aid for sustainable initiatives as their government expenditure falls and population rises. In the recipients' needs model, this study found strong evidence between the sustainable aid and four important variables of Coal production, Coal consumption, $\mathrm{CO}_{2}$ emissions and $\mathrm{HDI}$. This stresses on the fact that recipient countries need to lower their $\mathrm{CO}_{2}$ emissions and production and consumption of coal for them to receive more aid for the sustainable production and consumption sector. This result was also supported by the HDI variable, where as a country's performance in HDI ranking becomes better, the more aid they would receive. This proves the fact that donors provide more aid to a country which is relatively cleaner. The results of the third model of good governance, where in line with those of the second model. This model also re-iterates that as a recipient country becomes cleaner in terms of production and emissions along with its increased governance effectiveness, they tend to receive more aid. Also, the good governance in the donor country was not an important factor in making their aid allocation decisions. The study did not find any statistical evidence in the fragile state priority model. This is obvious to expect as the good governance and the fragile states models are contrary to each other.

Although this study attempted to produce empirical evidence within a possible range, at has one limitation, wherein it used a rational choice model for the theoretical framework which presumes that the both the donors and recipients are in a static condition. However, the aid allocation arena could be more complex and interrelated or independent among donors, between donors and recipient countries, and also among recipient countries. Thus, this arena may need a dynamic perspective to more precisely understand the allocation phenomena. Future study is needed to consider this perspective by using a theory that helps to explain the dynamics, such as game theory, the principle-agent relationship, the logic of collective action and free rider theory.

\section{Declarations}




\section{Acknowledgment}

The authors are grateful to the host institutions for providing the infrastructure and facilities for carrying out the research.

\section{References}

1. Addison, T., Gisselquist, R., Niño-Zarazúa, M., Singhal, S. "Needs vs expediency. Poverty reduction and social development in post-conflict countries". In: Arnim, L., Brown, G.K. (Eds.), Building Sustainable Peace: Timing and Sequencing of Post- Conflict Reconstruction and Peacebuilding. Volume 1(2016): Issues and Dynamics (Arnim Lang). Oxford University Press, Oxford.

2. Alesina, A., Dollar, D. “Who gives foreign aid to whom and why?”. J. Econ. Growth 5 (1),(2000): 3363.

3. Anderson, J.E. "Public Policymaking, 3rd ed.". Houghton Mifflin,(1997). Boston.

4. Berthélemy, J.C. "Bilateral donors' interest vs. recipients' development motives in aid allocation: do all donors behave the same?". Rev. Dev. Econ. 10 (2), (2006): 179-194.

5. Blundell, R., Bond, S. "Initial conditions and moment restrictions in dynamic panel data models". J. Econom. 87 (1998): 115-143.

6. Chambers, P.E., Dutcher, E.G. and Isaac, R.M. "Improving environmental quality through aid: An experimental analysis of aid structures with heterogeneous agents". Ecological economics, 146 (2018): pp.435-446.

7. Claessens, S., Cassimon, D., Van Campenhout, B. "Evidence on changes in aid allocation criteria". World Bank Econ. Rev. 23 (2), (2009):185-208.

8. Davenport, M. "The allocation of foreign aid: a cross section study, with special reference to the Pearson commission report". Yorkshire Bull. Econ. Social Res. 22 (1), (1970): 26-42.

9. De Matteis, A. "Relevance of poverty and governance for aid allocation". Review of Development Finance, 3(2), (2013): pp.51-60.

10. Dreher, A., Nunnenkamp, P., Thiele, R. "Are new donors different? Comparing the Allocation of Bilateral Aid between Non DAC and DAC Donor Countries ". World Dev. 39 (11), (2011): 1950-1968.

11. Edgeworth, F.Y. "Mathematical Psychics: An Essay on the Application of Mathematics to the Moral Science". C.K. Paul \& Co. (1881), London.

12. Fielding, D. "Health Aid and Governance in Developing Countries". Health Econ. 20 (7), (2011): 757769.

13. Fuchs, A., Vadlamannati, K.C. "The needy donor: an empirical analysis of India's aid Motives”. World Dev. 44 (2013): 110-128.

14. Irfan, Z. B., \& Nehra, A. (2016). Analysing the aid effectiveness on the living standard: A check-up on Southeast Asian countries. Journal of Urban Management, 5(1), 23-31. 
15. Kim, H.J., Lee, H.J. and Yoo, S.H. "Are South Korean people willing to pay for official development assistance for building renewable power plants in developing countries?". Energy Policy, 118 (2018): pp.626-632.

16. Kosack, S. "Effective aid: How democracy allows development aid to improve the quality of life". World Development, 31(1), (2003): pp.1-22.

17. Kuziemko, I., Werker, E. "How much is a seat on the security council worth?: Foreign aid and bribery at the United Nations." Political Econ. 114 (5), (2006): 905-930.

18. Lee, S.A., Lim, J.-Y. "Does international health aid follow recipients' needs? Extensive and intensive margins of health aid allocation". World Dev. 64 (C), (2014): 104 - 120.

19. Le Quéré, C., Andrew, R.M., Friedlingstein, P., Sitch, S., Pongratz, J., Manning, A.C., Korsbakken, J.I., Peters, G.P., Canadell, J.G., Jackson, R.B. and Boden, T.A., 2017. "Global carbon budget 2017". Earth System Science Data Discussions, (2017): pp.1-79.

20. Liu, Q., Yan, Z. and Zhou, J. “Consumer choices and motives for eco-labeled products in China: An empirical analysis based on the choice experiment". Sustainability, 9(3), (2017): p.331.

21. Maizels, A., Missanke, M. “Motivation for Aid to Developing Countries". World Dev. 12 (1984): 879900.

22. McKinlay, R., Little, R." A foreign policy model of U.S. bilateral aid allocation ". World Politics XXX (1), (1977).

23. McKinlay, R., Little, R. “ A foreign policy model of the distribution of British bilateral aid,1960-1970”. Br. J. Political Sci. 27 (2), (1978a) : 236-250.

24. McKinlay, R., Little, R. "The French aid relationship: a foreign policy model of the distribution of French bilateral aid, 1964-1970". Dev. Change 9.(1978b).

25. McKinlay, R., Little, R. "The US aid relationship: a test of the recipient need and the donor interest models". Political Stud, XXVII (2),(1979).

26. McManus, E., Collins, M., Yates, O., Sanders, M., Townhill, B., Mangi, S. and Tyllianakis, E. "Commonwealth SIDS and UK Overseas Territories sustainable fisheries programmes: An overview of projects and benefits of official development assistance funding". Marine Policy, (2019).

27. Nelson, R. "Does aid follow need? , Humanitarian Motivation in Aid Allocation. Aid Transparency and Development Finance: Lessons from AidData". University College, (2010) Oxford.

28. Neumayer, E. "The Determinants of Aid Allocation by Regional Multilateral Development banks and United Nations Agencies". Int. Stud. Q. 47 (2003): 101-122.

29. Neumayer, E. "Is the Allocation of Food Aid free from Donor Interest Bias?". J. Dev. Stud. 241 (3), (2005): 394-411.

30. Nickell, S.J. "Biases in dynamic models with fixed effects". Econometrica, 49 (1981): 1417-1426

31. Organization of Economic Cooperation and Development - Development Assistance Committee (OECD-DAC) statistics, March (2011). oecd.org/dac/stats/rioconventions 
32. Organization of Economic Cooperation and Development - Development Assistance Committee (OECD-DAC) statistics, November (2013). oecd.org/dac/stats/rioconventions.htm

33. Rahman, M.S. and Giessen, L. "Formal and informal interests of donors to allocate aid: Spending patterns of USAID, GIZ, and EU forest development policy in Bangladesh". World Development, 94 (2017): pp.250-267.

34. Sumida,S. "Donor's motivation of the Educational Aid". International Journal of Educational Development, 55 (2017): pp.17-29.

35. Todaro, M.P., Smith, S.C. “Economic Development,10th ed”. Pearson Education Limited, Aufl., Harlow[ua](2009) : Addison Wesley, England.

36. Turrent, V., Oketch, M.,. "Financing universal primary education:An Analysis of Official Development Assistance in Fragile States". Int. J. Educ. Dev. 29 (4), (2009): 357- 365.

37. Wittkopf, E.R. "Western Bilateral Aid Allocations: A Comparative Study of Recipient State Attributes and Aid Received". (1972).Sage Publ..

38. Younas, J. "Motivation for bilateral aid allocation: altruism or trade benefits". Eur. J. Political Econ. 24 (3), (2008): 661-674.

\section{Figures}

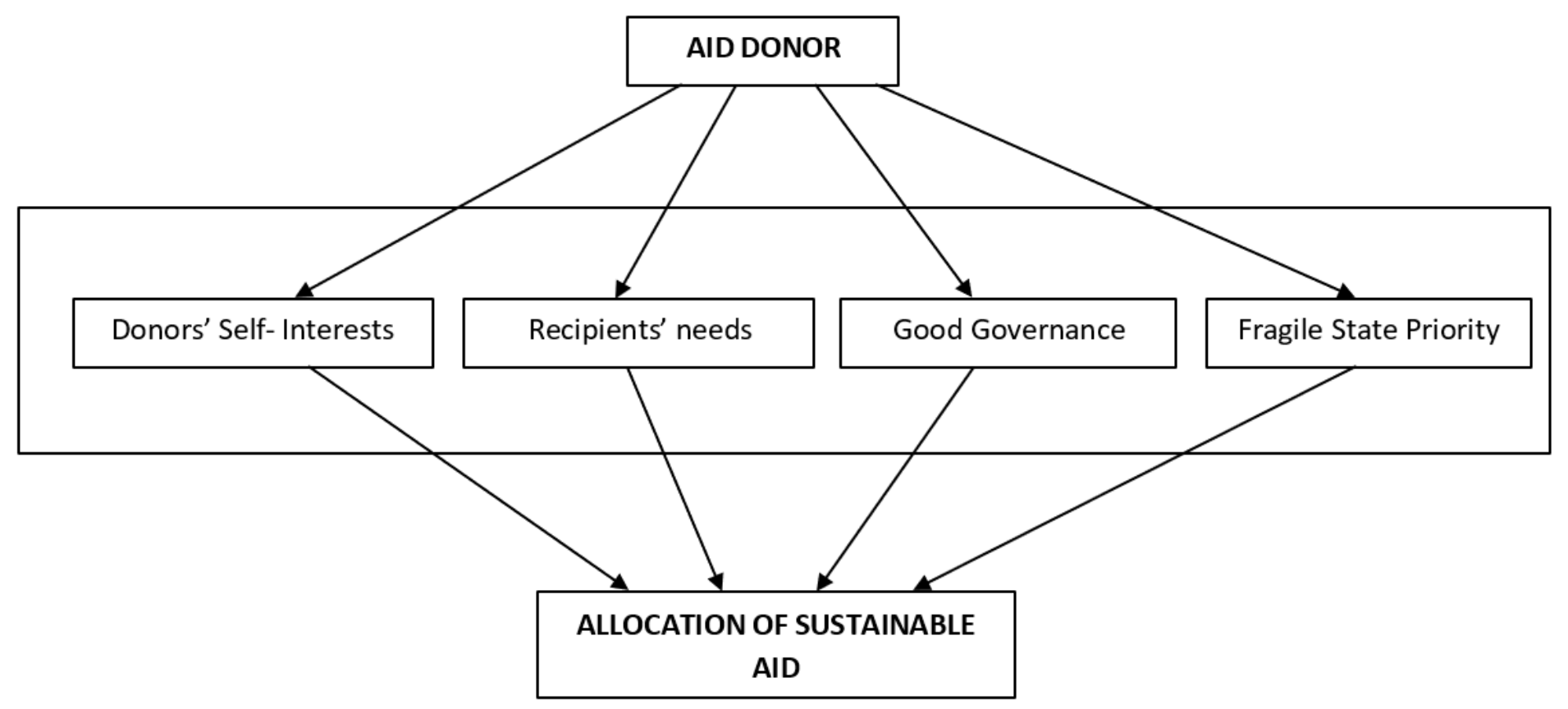

\section{Figure 1}

Diagram of the rational choice models 